\title{
An investigation into
}

the impact of question

change on estimates of

General Health Status and

Healthy Life Expectancy

Michael Smith and

Chris White

Office for National Statistics

This article investigates the likely effects of incorporating the European Union Statistics on Income and Living Conditions (EU-SILC) general health question upon Office for National Statistics (ONS) estimates of general health and healthy life expectancy (HLE). The analysis indicates that while these estimates will undergo revision following the integration of the EU-SILC general health question, for the most part the underlying trend remains unaffected. Incorporation of the EU-SILC question in the reporting of UK health statistics will improve comparability with other EU member states, and provide a stronger indicator of functional health status. ONS will adopt the EU-SILC general health question exclusively from the reporting period 2006-08. However, to further clarify the implications of this transition, ONS will present two estimates of HLE based on the original and EU-SILC general health questions for the period 2005-07. This article has important implications for setting targets and monitoring progress in Public Sector Agreement Indicators for fitness for work beyond the state pension age and healthy ageing.

\section{Introduction}

The general health question contained within the European Union (EU) Statistics on Income and Living Conditions (SILC) Minimum European Health Module has been included in the General Household Survey (GHS) of Great Britain (GB) and the Continuous Household Survey (CHS) of Northern Ireland since 2005, following a joint World Health Organisation-EU recommendation to provide consistency across European countries. It is designed to capture the health status of populations, without regard to temporary health problems. ${ }^{1,2}$

The Office for National Statistics (ONS) currently uses a different question on general health, asked in the GHS and CHS, to calculate the prevalence of self-reported general health in GB and the United Kingdom (UK). There are two principal differences between this original question and the SILC general health question: firstly, the number of response categories increases from three to five in the latter; secondly, the reference to an explicit period of 12 months is excluded in the SILC question (Box One). These changes risk a discontinuity in the general health time series in GB, built up since 1977, and the revised healthy life expectancy (HLE) time series for the UK reported by the ONS since 2000-02. ${ }^{3}$ It is important to appraise this risk and investigate the source, direction and magnitude of any discontinuities that arise: firstly to promote user understanding of this change; secondly, to maintain the integrity of these indicators of population health.

HLE, defined as expected years of life in 'Good' health, is derived, in part, from the self-reported health of respondents sampled in the GHS and the CHS. ONS uses a simple dichotomised definition of health status to construct estimates of HLE: survey responses are collapsed into a binary 'Good' and 'Not good' health variable without account taken of intermediate states. This approach involves imposing an arbitrary cut-off 
point somewhere between the extremes of the scale. In the case of the SILC question (Box One), the EU definition of 'Good' health contains the response categories Very good and Good. This definition has been shown to improve identification of underlying inequality in health at a subnational level and is currently used for cross-national comparisons of self-reported general health within the EU., ${ }^{4,5}$ ONS will adopt this definition in its future reporting of HLE to improve coherence with other EU member states and set a benchmark for future estimates at local authority level.

\section{Box one}

\begin{tabular}{|c|c|}
\hline $\begin{array}{l}\text { Original general } \\
\text { health question } \\
\text { 'Over the last } \\
12 \text { months } \\
\text { would you say } \\
\text { your health has } \\
\text { on the whole } \\
\text { been...' }\end{array}$ & $\begin{array}{l}\text { Dichotomised } \\
\text { definition }\end{array}$ \\
\hline Good? & \multirow{2}{*}{ 'Good' health } \\
\hline Fairly good? & \\
\hline Not good? & $\begin{array}{l}\text { 'Not good' } \\
\text { health }\end{array}$ \\
\hline
\end{tabular}

\begin{tabular}{|l|l|}
\hline $\begin{array}{l}\text { Harmonised } \\
\text { SILC general } \\
\text { health } \\
\text { question } \\
\text { 'How is your } \\
\text { health in } \\
\text { general? Is it...' }\end{array}$ & \\
\cline { 1 - 2 } Very good? & $\begin{array}{l}\text { Dichotomised } \\
\text { definition }\end{array}$ \\
\hline Good? & 'Good' health \\
\hline Fair? & 'Not good' \\
\cline { 1 - 1 } & health \\
\hline Very bad? & \\
\hline
\end{tabular}

Footnote: In the text, references to self-reported and dichotomised health states will follow the conventions of the table above such that references to dichotomised health states will appear within quotation marks.

\section{Methods}

This paper considers two versions of the general health question asked in three different surveys during 2005-06: the GHS and CHS, which contain both the original and the SILC general health questions, and the Health Survey for England (HSE) which contains a question consistent with the SILC question.

The GHS and CHS have asked both the original and SILC general health questions since 2005 . The analysis presented here uses data from these surveys collected in 2005 and 2006. In 2005, the GHS changed to a longitudinal rotating panel design: the 2006 sample therefore consists of three-quarters of the 2005 sample, with the remaining quarter composed of new entrants to the survey. For this analysis, the use of 2006 GHS data is restricted to new survey entrants to maintain consistency with the cross-sectional nature of previous data used in the construction of estimates of HLE. Analyses of men and women in the UK, GB and England are presented. Separate analyses for Wales, Scotland and Northern Ireland were excluded because the available data on these countries were inadequate for meaningful comparison.

\section{External validation of survey response}

The SILC general health question follows the original question in both the GHS and CHS. The presence of two adjacent questions on general health status in the same survey has the potential for introducing bias, arising from ordering and exposure effects. These effects can obscure or distort the true effect of question change on the prevalence of 'Good' health and HLE. To assess the likely presence of these effects on responses to the SILC question, data from the GHS covering England were compared with a contemporaneous external data source, namely the HSE.

Responses to the general health question in the HSE 2005 and 2006 were compared with those of the English sample of the GHS over the same period. The prevalence of the different health states in each survey was age-standardised to the European standard population to control for possible differences in the age structure of the two samples.

\section{Comparison of self-reported health by question}

The prevalence of each health state was calculated from responses to the original and SILC general health questions and comparisons were made between both the dichotomised 'Good' and 'Not good' health states, according to question, and the prevalence of limiting longstanding illness (LLSI) in the survey populations. This latter comparison was undertaken to shed light on the possibility of differences in the relationship between subjective well-being, as measured with each question, and functional health status.

\section{Translation of survey responses and development of adjustment factors}

Self-reported responses to the original general health question in the GHS and CHS for the UK, GB and England in 2005-06 were mapped to subsequent responses to the SILC question, and an algorithm was developed to define the translation in self-reported health states between the questions. These translations were then further refined and used to simulate the dichotomised EU definition of 'Good' and 'Not good' health on historic GHS and CHS data.

Adjustment factors (Box Two) based on movements between selfreported health states from the original to the SILC question were applied to historic data by sex and discrete age groups (that is 16-19, 20-24, 25$29 \ldots 85+$ ), in order to simulate the adoption of the harmonised general health question on the existing time series of general health data. In the first instance, to validate this approach, comparisons were made between the proportions of people in 'Good' health, as defined using actual and simulated GHS (England) and HSE general health survey data between

\section{Box two}

\section{Adjustment factors}

Factors based on the translation of self-reported health states from the original to the harmonised SILC general health question were applied to historic data according to the following equation.

'Good' health $=\left(a_{i}-\left(a_{i} \alpha_{i}\right)\right)+\left(\left(b_{i} \beta_{i}\right)+\left(c_{i} \gamma_{i}\right)\right)$

'Not good' health $=\left(\left(b_{i}+c_{i}\right)+\left(a_{i} \alpha_{i}\right)\right)-\left(\left(b_{i} \beta_{i}\right)+\left(c_{i} \gamma_{i}\right)\right)$

$\mathrm{i}=$ age interval

$\mathrm{a}=$ number reporting Good health in response to original question

$b=$ number reporting Fairly good health in response to original question

$\mathrm{c}=$ number reporting Not good health in response to original question

$\alpha=$ proportion of respondents reporting Good health in response to the original general health question and who subsequently report Fair or Bad or Very bad health in response to the harmonised general health question.

$\beta=$ proportion of respondents reporting Fairly good health in response to the original general health question and who subsequently report Good or Very good health in response to the harmonised general health question.

$\gamma=$ proportion of respondents reporting Not good health in response to the original general health question and who subsequently report Good or Very good health in response to the harmonised general health question.

Proportions of people originally reporting Fairly good health and who subsequently reported Fair, Bad or Very bad health are not included in the equation since this proportion of people does not affect the overall proportion of people appearing in 'Good' or 'Not good' health according to the new dichotomy. Similarly proportions of people reporting Not good health and who subsequently report Fair health are also not included. 
1991-93 and 2004-06. Further comparisons were made between actual and simulated GHS (GB) data between 1980-82 and 2004-06. Tables of adjustment factors applied to actual data to derive simulated estimates of the prevalence of 'Good' health in the population from the SILC general health question are shown in the Appendix, Tables A1-A4.

\section{Calculation of healthy life expectancy}

ONS reports HLE for the UK and constituent countries. HLE is derived partly from survey responses and is defined as the expected years of life in 'Good' health (Box One). HLE is calculated using the Sullivan method incorporating national period life expectancies. ${ }^{6,7}$ Briefly, the prevalence of self-reported 'Good' and 'Not good' health by country, sex and five-year age band is calculated from responses to the GHS and CHS, and aggregated over three years. Because the GHS and CHS do not include residents of communal establishments, such as nursing homes, the prevalence of the various health states in this population is based on data from the 2001 Census for all the years covered. The proportion of the population residing in communal establishments is adjusted to match current aggregated mid-year population estimates.

A combined survey and communal establishment health state prevalence is multiplied by the total person years lived at a given age interval, calculated from aggregated mid-year population estimates and period life tables, to give the total number of person years lived at that age interval in 'Good' and 'Not good' health. The total number of person years in 'Good' health at a given age is then divided by the number of people surviving to that age to give an estimate of HLE. The methods and the data sources used to calculate health expectancies are reported in further detail in the article 'Review of sources and methods to monitor healthy life expectancy' published in Health Statistics Quarterly $26^{6}$

\section{Impact of general health question change on healthy life expectancy time series}

It is well established that self-reported health is significantly associated with age, sex and socio-economic position..$^{8,9,10,11,12,13}$ The presence of these relationships in GHS and CHS data from 2005-06 was explored using multiple logistic regression modelling, with the idea of refining the translation algorithm further. A sample member's socio-economic position was determined by assigning the condensed, 3 -analytic class National Statistics Socio-economic Classification of the household reference person (HRP NS-SEC). ${ }^{14}$ The results are presented in Table A5 in the Appendix.

In an approach designed to simulate the effects of adopting the SILC general health question on estimates of HLE between 2000-02 and 2004-06, adjustment factors (Box Two), taking account of the HRP's NS-SEC, were applied to GHS data over this period and to CHS data between 2001-03 and 2004-06 (HRP NS-SEC was not available for the CHS in 2000) to derive adjusted proportions of 'Good' and 'Not good' health in each year and calculate 'simulated' estimates of HLE. These were compared with the original estimates to ascertain dissonance. Tables of adjustment factors by age and sex and HRP NS-SEC for the UK, GB and England are shown in the Appendix, Tables A6-A11.

\section{Results}

\section{Comparison of responses to the SILC general health question in the GHS (England) and HSE}

The age-standardised prevalence of self-reported health states calculated from responses to the SILC general health question in the GHS (England only sample) and the HSE for 2005-06 are shown in Table 1.
Overall, the proportion of respondents reporting their general health as Very good was higher in the GHS than in the HSE, while proportions of respondents reporting either Good or Very bad were lower. There were no differences in the distribution of self-reported general health states between surveys among females (data not shown), but among males selfreports of Very good and Very bad differed: the proportion of respondents reporting Very good health was higher in the GHS (42.8 per cent \pm 0.8 (95 per cent confidence interval (CI))) than in the HSE ( 40.5 per cent \pm 0.8 (95 per cent $\mathrm{CI})$ ); the proportion of respondents reporting Very bad health was lower in the GHS $(0.7$ per cent \pm 0.2 (95 per cent $\mathrm{CI})$ ) than the HSE (1.2 per cent \pm 0.2 (95 per cent CI)).

After dichotomising responses to the European definition (Box One), no difference in the prevalence of 'Good' health between the GHS and HSE was observed: the proportion of the population in 'Good' health as a whole was approximately 81 per cent in both surveys. Similarly, no difference was observed for males or females in the two surveys (data not shown).

\section{Table 1}

Comparison of age-standardised' ${ }^{1}$ self-reported health rates between the General Household Survey (England) (GHS) and the Health Survey for England (HSE) in 2005-06, all ages

\begin{tabular}{l|l|c|c|c}
\hline & $\begin{array}{c}\text { Response } \\
\text { category }\end{array}$ & Per cent & $\begin{array}{c}\text { Lower 95 per } \\
\text { cent confidence } \\
\text { interval }\end{array}$ & $\begin{array}{c}\text { Upper 95 per } \\
\text { cent confidence } \\
\text { interval }\end{array}$ \\
\hline GHS (Harmonised SILC) & Very good & $41.9^{*}$ & 41.3 & 42.4 \\
How is your health in & Good & $39.6^{*}$ & 39.0 & 40.3 \\
general? Is it... & Fair & 13.6 & 13.3 & 14.0 \\
& Bad & 3.9 & 3.7 & 4.2 \\
& Very bad & $0.9^{*}$ & 0.8 & 1.0 \\
Dichotomised 'Good' health & & 81.5 & 81.0 & 82.0 \\
Sample size n= 25,986 & & & & \\
HSE** How is your health & Very good & $40.1^{*}$ & 39.6 & 40.7 \\
in general? Would you say & Good & $41.1^{*}$ & 40.5 & 41.7 \\
it was... & Fair & 13.9 & 13.6 & 14.3 \\
& Bad & 3.7 & 3.5 & 3.9 \\
Dichotomised 'Good' health & Very bad & $1.1^{*}$ & 1.0 & 1.2 \\
Sample size n = 30,922 & & 81.2 & 80.8 & 81.6 \\
\hline
\end{tabular}

1 Directly age-standardised rate using the European standard population.

* Significant difference between General Household Survey (England) and the Health Survey for England.

* * Source: Department of Health

\section{Comparison of responses to original and SILC general health questions 2005-06}

The distribution of responses to the original and SILC questions in the UK, GB and England using GHS and CHS data are shown in Table 2.

Self-reported general health was consistent across countries in question specific responses. For example, in the UK, GB and England a less than 0.8 per cent variation in responses to each question was observed.

After dichotomising responses, the total prevalence of 'Good' health was 9 per cent lower using the SILC question compared to the original. This margin of difference ( 9 per cent) was the same for both males and females.

The prevalence of LLSI in the survey populations was observed to increase with worsening self-reported general health (Table 3). The dichotomised general health states also conformed to this pattern, but to a different degree of magnitude for each definition: a significantly greater proportion of people defined in 'Good' health under the existing definition reported having a LLSI than did under the EU definition of 'Good' health (11.7 per cent compared with 7.8 per cent respectively in the UK). 


\begin{tabular}{|c|c|c|c|c|c|c|c|c|c|c|}
\hline & \multirow[b]{2}{*}{$\begin{array}{l}\text { Response } \\
\text { category }\end{array}$} & \multicolumn{3}{|c|}{ United Kingdom } & \multicolumn{3}{|c|}{ Great Britain } & \multicolumn{3}{|c|}{ England } \\
\hline & & Per cent & $\begin{array}{c}\text { Lower } 95 \text { per } \\
\text { cent confidence } \\
\text { interval }\end{array}$ & $\begin{array}{c}\text { Upper } 95 \text { per } \\
\text { cent confidence } \\
\text { interval }\end{array}$ & Per cent & $\begin{array}{c}\text { Lower } 95 \text { per } \\
\text { cent confidence } \\
\text { interval }\end{array}$ & $\begin{array}{c}\text { Upper } 95 \text { per } \\
\text { cent confidence } \\
\text { interval }\end{array}$ & Per cent & $\begin{array}{c}\text { Lower } 95 \text { per } \\
\text { cent confidence } \\
\text { interval }\end{array}$ & $\begin{array}{c}\text { Upper } 95 \text { per } \\
\text { cent confidence } \\
\text { interval }\end{array}$ \\
\hline \multirow{3}{*}{$\begin{array}{l}\text { Original Over the last } 12 \text { months } \\
\text { would you say your health has } \\
\text { on the whole been ... }\end{array}$} & Good & 64.4 & 64.0 & 64.9 & 64.6 & 64.1 & 65.1 & 64.8 & 64.2 & 65.4 \\
\hline & Fairly good & 23.7 & 23.3 & 24.2 & 23.6 & 23.1 & 24.1 & 23.6 & 23.1 & 24.1 \\
\hline & Not good & 11.8 & 11.5 & 12.2 & 11.8 & 11.4 & 12.2 & 11.6 & 11.2 & 12.0 \\
\hline Dichotomised 'Good' health & & 88.2 & 87.8 & 88.5 & 88.2 & 87.8 & 88.6 & 88.4 & 88.0 & 88.8 \\
\hline \multirow{5}{*}{$\begin{array}{l}\text { Harmonised SILC How is your } \\
\text { health in general? Is it... }\end{array}$} & Very good & 40.4 & 40.0 & 40.9 & 40.1 & 39.5 & 40.7 & 39.7 & 39.1 & 40.3 \\
\hline & Good & 38.8 & 38.4 & 39.3 & 38.9 & 38.4 & 39.5 & 39.5 & 38.9 & 40.1 \\
\hline & Fair & 14.7 & 14.3 & 15.0 & 15.1 & 14.7 & 15.5 & 15.2 & 14.8 & 15.6 \\
\hline & Bad & 5.0 & 4.8 & 5.2 & 4.7 & 4.5 & 2.7 & 4.5 & 4.3 & 4.8 \\
\hline & Very bad & 1.1 & 1.0 & 1.2 & 1.1 & 1.0 & 1.2 & 1.0 & 0.9 & 1.2 \\
\hline \multicolumn{2}{|l|}{ Dichotomised 'Good' health } & 79.3 & 78.9 & 79.7 & 79.0 & 78.5 & 79.5 & 79.2 & 78.7 & 79.7 \\
\hline \multicolumn{2}{|l|}{ Sample size } & $n=40,348$ & & & $\mathrm{n}=30,125$ & & & $\mathrm{n}=25,981$ & & \\
\hline
\end{tabular}

\begin{tabular}{|c|c|c|c|c|c|c|c|c|c|c|}
\hline & \multirow[b]{2}{*}{$\begin{array}{l}\text { Response } \\
\text { category }\end{array}$} & \multicolumn{3}{|c|}{ United Kingdom } & \multicolumn{3}{|c|}{ Great Britain } & \multicolumn{3}{|c|}{ England } \\
\hline & & $\begin{array}{l}\text { Per cent also } \\
\text { reporting LLSI }\end{array}$ & $\begin{array}{c}\text { Lower } 95 \text { per } \\
\text { cent confidence } \\
\text { interval }\end{array}$ & $\begin{array}{c}\text { Upper } 95 \text { per } \\
\text { cent confidence } \\
\text { interval }\end{array}$ & $\begin{array}{l}\text { Per cent also } \\
\text { reporting LLSI }\end{array}$ & $\begin{array}{c}\text { Lower } 95 \text { per } \\
\text { cent confidence } \\
\text { interval }\end{array}$ & $\begin{array}{c}\text { Upper } 95 \text { per } \\
\text { cent confidence } \\
\text { interval }\end{array}$ & $\begin{array}{l}\text { Per cent also } \\
\text { reporting LLSI }\end{array}$ & $\begin{array}{c}\text { Lower } 95 \text { per } \\
\text { cent confidence } \\
\text { interval }\end{array}$ & $\begin{array}{l}\text { Upper } 95 \text { per } \\
\text { cent confidence } \\
\text { interval }\end{array}$ \\
\hline \multirow{3}{*}{$\begin{array}{l}\text { Original Over the last } 12 \text { months } \\
\text { would you say your health has } \\
\text { on the whole been ... }\end{array}$} & Good & 5.1 & 4.8 & 5.4 & 5.2 & 4.9 & 5.6 & 5.4 & 5.0 & 5.7 \\
\hline & Fairly good & 29.7 & 28.8 & 30.6 & 28.8 & 27.8 & 29.9 & 28.4 & 27.3 & 29.6 \\
\hline & Not good & 76.7 & 75.5 & 77.9 & 75.1 & 73.6 & 76.5 & 74.0 & 72.4 & 75.5 \\
\hline Dichotomised 'Good' health & & 11.7 & 11.4 & 12.1 & 11.6 & 11.2 & 11.9 & 11.5 & 11.1 & 11.9 \\
\hline \multirow{5}{*}{$\begin{array}{l}\text { Harmonised SILC How is your } \\
\text { health in general? Is it... }\end{array}$} & Very good & 3.0 & 2.8 & 3.3 & 3.2 & 2.9 & 3.5 & 3.3 & 2.9 & 3.6 \\
\hline & Good & 12.7 & 12.2 & 13.3 & 12.5 & 11.9 & 13.1 & 12.5 & 11.9 & 13.2 \\
\hline & Fair & 53.8 & 52.5 & 55.0 & 51.5 & 50.0 & 52.9 & 50.4 & 48.9 & 52.0 \\
\hline & Bad & 88.2 & 86.7 & 89.5 & 86.8 & 84.9 & 88.5 & 86.4 & 84.3 & 88.2 \\
\hline & Very bad & 92.6 & 89.8 & 94.7 & 92.3 & 88.9 & 94.7 & 91.5 & 87.6 & 94.3 \\
\hline \multicolumn{2}{|l|}{ Dichotomised 'Good' health } & 7.8 & 7.5 & 8.1 & 7.8 & 7.4 & 8.1 & 7.9 & 7.5 & 8.3 \\
\hline \multicolumn{2}{|l|}{ Sample size } & $\mathrm{n}=40,318$ & & & $\mathrm{n}=30,090$ & & & $\mathrm{n}=25,961$ & & \\
\hline
\end{tabular}

\section{Translation of health states}

The consistency of survey participants' self-reported health in response to each question was compared to determine a possible change to the underlying distribution of general health status as estimated in response to the original question: the analysis observed self-reported health in response to the SILC question to be somewhat better than their original rating (Table 4 and Figure 1).

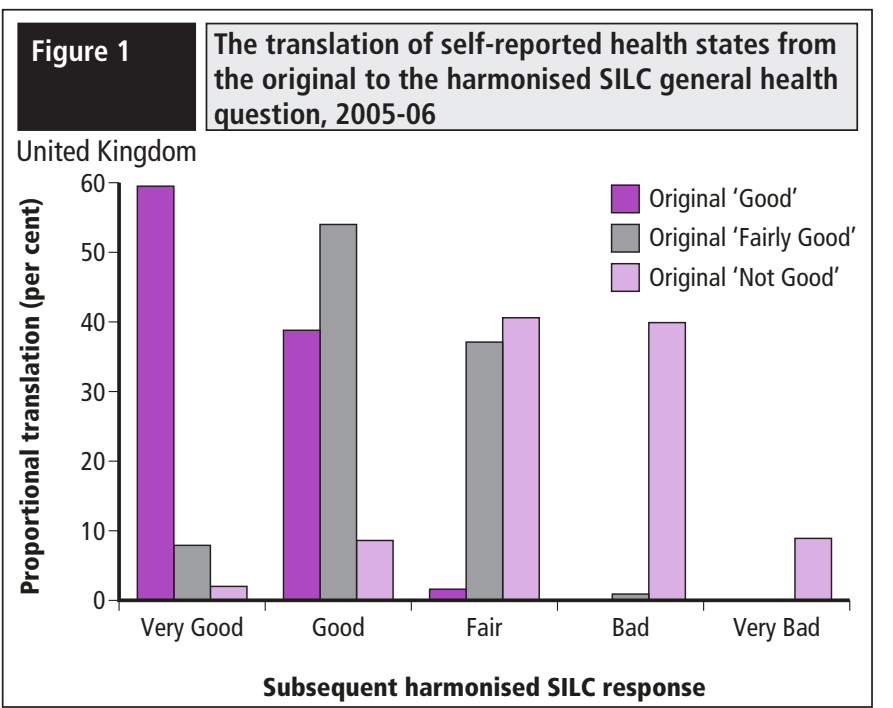

\section{Table 4}

Translation of health reporting from original to harmonised SILC general health questions, 2005-06

United Kingdom

Response to original general $\quad$ Subsequent reporting of health in response to SILC general health question

\begin{tabular}{lc|c|c|c|c}
\hline & Very good & Good & Fair & Bad & Very bad \\
\hline Good & 59.5 & 38.8 & 1.6 & - & - \\
Fairly good & 7.9 & 54.0 & 37.1 & 0.9 & - \\
Not good & 2.0 & 8.6 & 40.6 & 39.9 & 8.9 \\
\hline
\end{tabular}

Results for the UK show that more than half of respondents (51.2 per cent) who reported their general health in the category Not good in response to the original general health question, subsequently reported Fair or a better health state in response to the SILC question; similarly 61.9 per cent of those who reported Fairly good health under the original question subsequently reported Good or Very good health under the SILC general health question. For a small proportion of people, health states worsened: under the original general health question 1.6 per cent of people who reported Good health and 0.9 per cent of people who reported Fairly good health subsequently reported worse health states in response to the SILC question. 


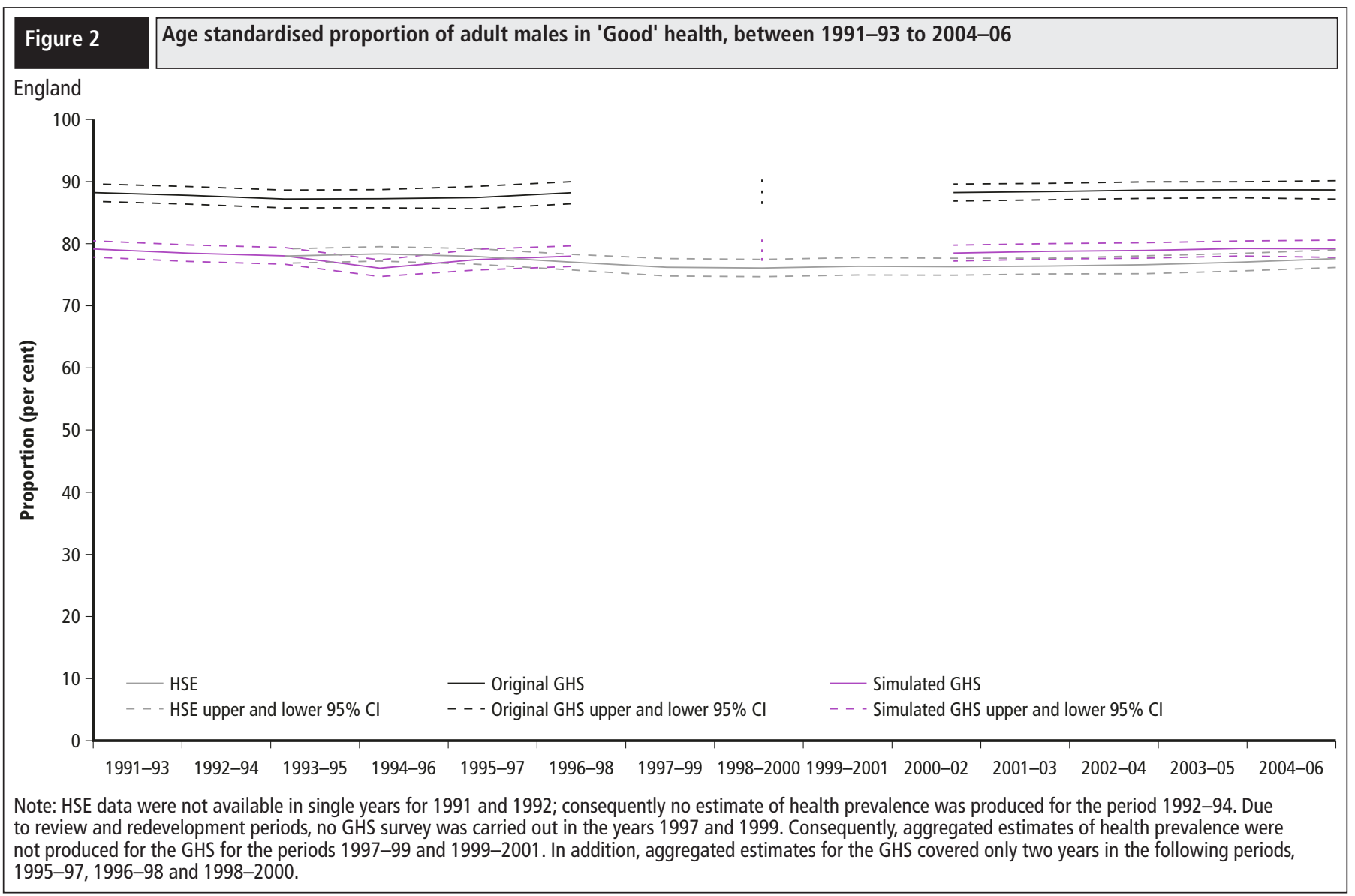

\section{$\begin{array}{lll}\text { Figure } 3 & \text { Age standardised proportion of adult females in 'Good' health, between 1991-93 to 2004-06 }\end{array}$}

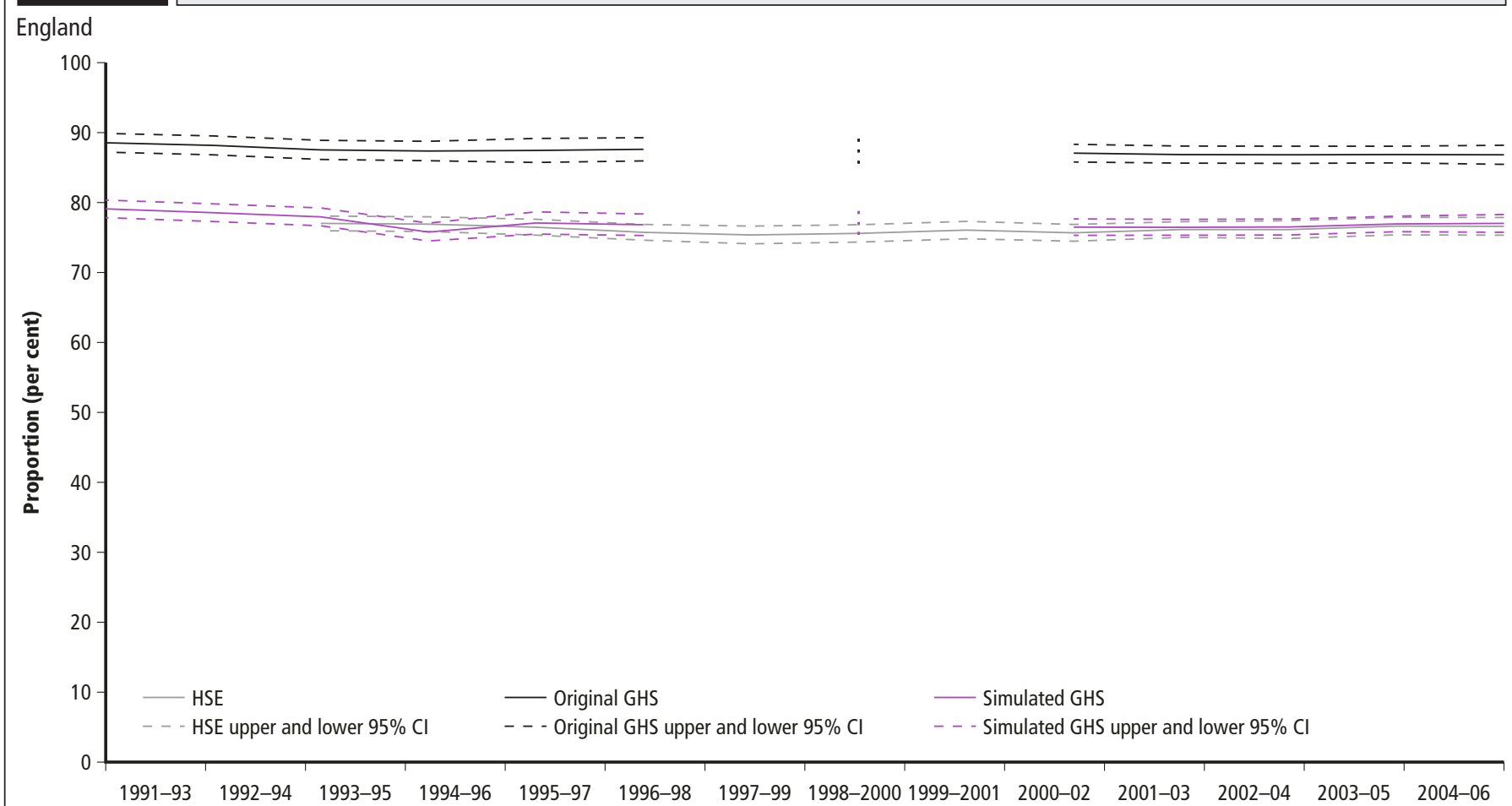

Note: HSE data were not available in single years for 1991 and 1992; consequently no estimate of health prevalence was produced for the period 1992-94. Due to review and redevelopment periods, no GHS survey was carried out in the years 1997 and 1999. Consequently, aggregated estimates of health prevalence were not produced for the GHS for the periods 1997-99 and 1999-2001. In addition, aggregated estimates for the GHS covered only two years in the following periods, $1995-97,1996-98$ and $1998-2000$. 


\section{Simulating the adoption of the SILC general health question on historic survey data}

The age-standardised prevalence of 'Good' health for adult males and females in England between 1991-93 and 2004-06, calculated using original and simulated GHS (England) data and HSE data, are shown in Figures 2 and 3. Estimates of the prevalence of 'Good' health for males and females over this period were consistently around 10 per cent higher in original compared to simulated GHS and HSE data. There was no difference between HSE and simulated GHS estimates.

The prevalence of 'Good' health using original and simulated GHS data for adult males and females in GB between 1980-82 and 2004-06 are shown in Figures 4 and 5.

The proportion of males and females in 'Good' health is lower in simulated, compared to original, GHS data. On average between 1980-82 and 2004-06, 87.6 per cent of men and 87.0 per cent of women were in 'Good' health according to original data compared to 76.6 per cent of men and 75.5 per cent of women in this health state over the same period according to simulated data. Simulation resulted in an average reduction in the proportion of 'Good' health by around 11 per cent (range $=10.4$ to 11.7 ) for men and around 11.5 per cent (range $=10.8$ to 12.3 ) for women. Thus, there was good consistency over time, with a variation between original and simulated data of around 1.3 per cent for men and 1.5 per cent for women. Overall, between 1980-82 and 2004-06, the prevalence of 'Good' health declined for males by 3 per cent in both original and simulated data; for females there was a 0.6 per cent decline observed in original data, but no change in simulated data.

\section{Impact on estimates of healthy life expectancy}

Estimates of HLE for the current time series (2000-02 to 2004-06) were compared to simulated estimates calculated using age, sex and HRP NS-SEC specific adjustment factors applied to historic survey data over the period 2000-02 to 2004-06 for the GHS and 2001-03 to 2004-06 for the CHS.

Original and simulated estimates of HLE for men and women at birth and at age 65 in the UK, GB and England are shown in Tables 5 and 6.

The original estimates of HLE were significantly higher than simulated estimates for men and women at birth and at age 65 in the UK, GB and England for each period in the time series. For men at birth, simulated HLE was between 9.5 and 10.2 per cent lower, equating to a fall of between 6.4 and 7.0 years of estimated life spent in 'Good' health compared to published estimates derived from original data. At age 65, simulated estimates of HLE were between 21.8 and 25.0 per cent lower than original estimates, equating to a loss of between 2.6 and 3.1 years of life in 'Good' health. The falls in estimated HLE for women were greater than for men, with a loss of between 10.7 to 11.6 per cent, or 7.5 to 8.1 years, at birth and between 24.4 and 26.4 per cent, or between 3.5 to 3.8 years, at age 65 in simulated compared to original estimates.

There were no significant differences in trends over time between estimates of HLE for the UK, GB and England using either original or simulated data for men or women at birth or at age 65. HLE for women was greater than for men at birth and at age 65 in the UK, GB and England and the magnitude of these differences is declining over time according to both original and simulated estimates.

Between 2000-02 and 2004-06, original estimates of HLE for men rose by 1.4 years at birth and 0.9 years at age 65 for both GB and England. The increase in HLE for simulated estimates was slightly lower at 0.9 years and 1.2 years for GB and England, respectively, at birth and 0.6 years for both
GB and England at age 65. For women, the increases in original estimates were 0.6 years at birth and 0.5 years at age 65 for GB and England. The increase in HLE according to simulated estimates for women were more variable with a smaller increase of 0.5 years for $\mathrm{GB}$, and a larger increase of 0.9 years for England, at birth and a smaller increase of 0.4 years for $\mathrm{GB}$, and equivalent increase ( 0.5 years) for England, at age 65 .

The changes in the proportion of life spent in 'Good' health (HLE divided by life expectancy) between 2000-02 and 2004-06 was also variable: for men at birth the proportion of life in 'Good' health rose slightly by 0.4 per cent in GB and England in original estimates; however, in simulated estimates, there was an equivalent increase in England ( 0.4 per cent); but in GB there was a slight decrease ( 0.1 per cent). For women at birth, original estimates of the proportion of life spent in 'Good' health decreased by 0.3 per cent over the period for both GB and England; however, in simulated estimates, while an equivalent decrease was observed for GB ( 0.3 per cent), there was an increase of 0.3 per cent in England.

At age 65, changes over time in the proportion of life spent in 'Good' health differ more markedly for men: specifically, increases of 1.2 per cent and 1.3 per cent (GB and England, respectively) in original estimates contrast with a decrease of 0.2 per cent in GB and an increase of 0.2 per cent in England observed in simulated estimates. For women, the proportion of life in 'Good' health between 2000-02 and 2004-06 using the original estimates decreased by 0.1 per cent in GB and by 0.3 per cent in England; however, there was no change in simulated estimates over this period in GB but an increase of 0.4 per cent was observed in England.

\section{Discussion}

This article has investigated the implications of using the SILC general health question (asked on UK national household surveys from 2008), for national estimates of HLE calculated by ONS. The future use of the SILC question to define the general health of survey respondents will result in a clear reduction in prevalence of 'Good' health in the UK and constituent countries. The principal driver of this decrease is the use of the dichotomised European definition of 'Good' health (Box One), which is conceptually less inclusive than the current definition derived from the original general health question. ${ }^{5}$ Our understanding of the impact of this change in the prevalence of 'Good' health in the population, and thereby estimates of HLE, has been assisted by the inclusion of the SILC general health question in both the GHS and CHS since 2005.

\section{Response bias}

The placement and concurrence of the two general health questions in the 2005 and 2006 GHS and CHS samples risks the introduction of bias resulting from exposure and order effects. This was assessed by comparing the responses to the SILC question in the GHS (England) with responses to an identical question asked in the HSE. It was found that while there were differences in the proportions of some responses between surveys, particularly for men, these differences attenuated in comparisons using the dichotomised EU definition of 'Good' health. It is beyond the scope of this study to ascertain whether the differences observed between the surveys were due to inter-survey variability, question exposure, question order or mode effects (see Kalton and Schuman for a detailed review of the complex issues surrounding the effects of question design and order on participant response).${ }^{15}$ However, the small differences detected in dichotomised responses suggests any possible exposure and order effects are unlikely to invalidate comparisons of the prevalence of 'Good' health using different definitions and, by implication, estimates of HLE. Consequently, the potential impact of adopting the SILC general health question on future estimates of HLE can be adequately assessed using GHS and CHS data from 2005 and 2006. 

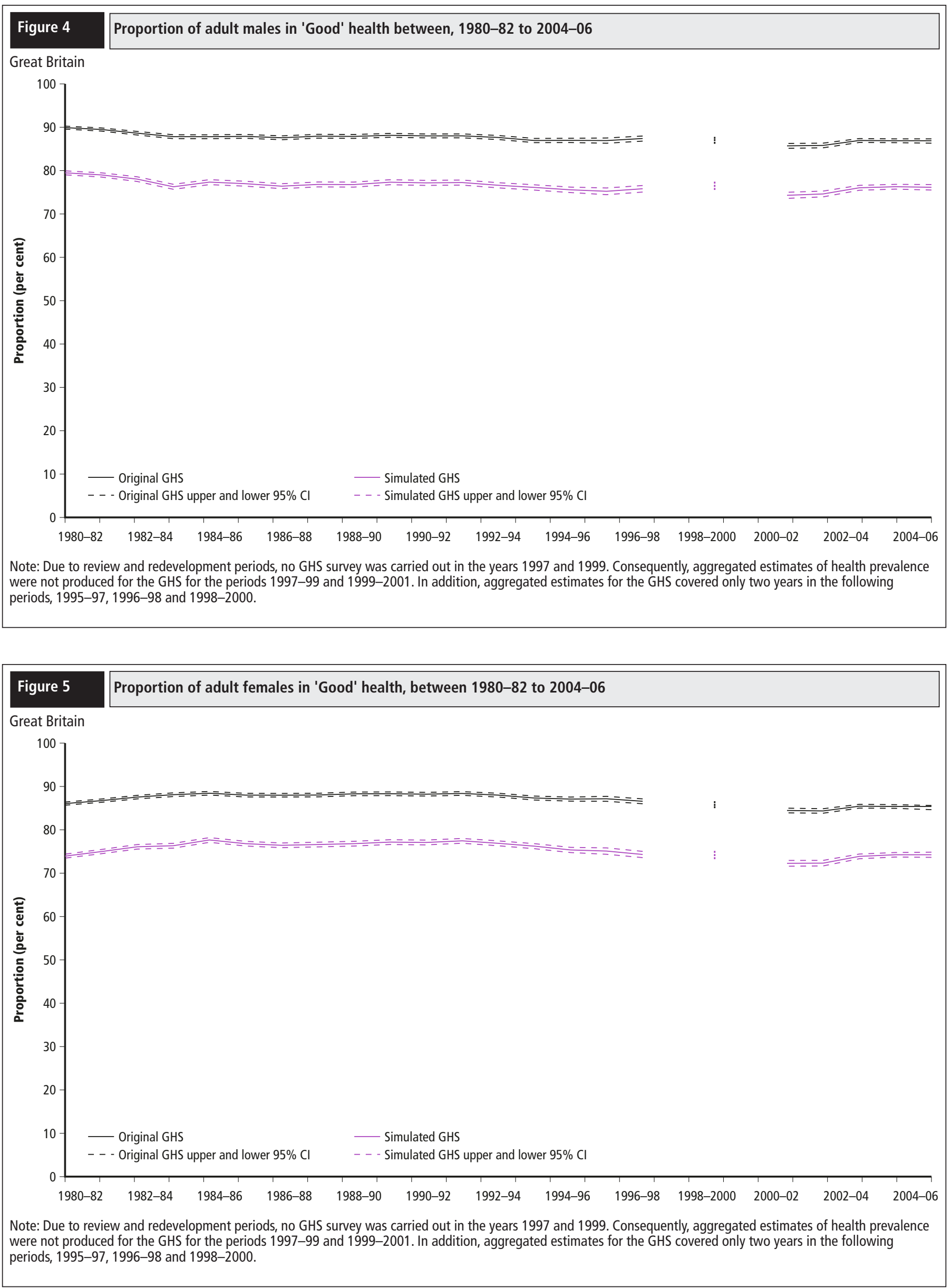


\begin{tabular}{|c|c|c|c|c|c|c|c|c|c|c|c|c|}
\hline \multirow[b]{2}{*}{ Year } & \multirow[b]{2}{*}{ Country } & \multirow[b]{2}{*}{$\begin{array}{l}\text { Life } \\
\text { expectancy } \\
\text { (Years) }\end{array}$} & \multicolumn{4}{|c|}{ Original survey data } & \multicolumn{4}{|c|}{ Simulated survey data } & \multirow{2}{*}{$\begin{array}{l}\text { Decrease in } \\
\text { HLE between } \\
\text { original and } \\
\text { simulated } \\
\text { survey data } \\
\text { (per cent) }\end{array}$} & \multirow{2}{*}{$\begin{array}{l}\text { Difference } \\
\text { between } \\
\text { original and } \\
\text { simulated } \\
\text { survey data } \\
\text { (Years) }\end{array}$} \\
\hline & & & $\begin{array}{c}\text { Healthy life } \\
\text { expectancy } \\
\text { (Years) }\end{array}$ & $\begin{array}{l}\text { Lower } 95 \\
\text { per cent } \\
\text { confidence } \\
\text { interval }\end{array}$ & $\begin{array}{l}\text { Upper } 95 \\
\text { per cent } \\
\text { confidence } \\
\text { interval }\end{array}$ & $\begin{array}{c}\text { Proportion of } \\
\text { life in 'Good' } \\
\text { health } \\
\text { (per cent) }\end{array}$ & $\begin{array}{c}\text { Healthy life } \\
\text { expectancy } \\
\text { (Years) }\end{array}$ & $\begin{array}{l}\text { Lower } 95 \\
\text { per cent } \\
\text { confidence } \\
\text { interval }\end{array}$ & $\begin{array}{l}\text { Upper } 95 \\
\text { per cent } \\
\text { confidence } \\
\text { interval }\end{array}$ & $\begin{array}{c}\text { Proportion of } \\
\text { life in 'Good' } \\
\text { health } \\
\text { (per cent) }\end{array}$ & & \\
\hline $\begin{array}{l}\text { At birth } \\
2000-02\end{array}$ & $\begin{array}{l}\text { United Kingdom } \\
\text { Great Britain } \\
\text { England }\end{array}$ & $\begin{array}{l}75.7 \\
75.7 \\
76.0\end{array}$ & $\begin{array}{l}66.8 \\
66.8 \\
67.1\end{array}$ & $\begin{array}{l}66.5 \\
66.5 \\
66.8\end{array}$ & $\begin{array}{l}67.0 \\
67.1 \\
67.4\end{array}$ & $\begin{array}{l}88.2 \\
88.3 \\
88.3\end{array}$ & $\begin{array}{l}60.0 \\
60.3\end{array}$ & $\begin{array}{l}60 . \ddot{1} \\
59.9\end{array}$ & $\begin{array}{l}60.8 \\
60.7\end{array}$ & $\begin{array}{l}79 . \ddot{9} \\
79.3\end{array}$ & $\begin{array}{r}9 . \ddot{5} \\
10.2\end{array}$ & $\begin{array}{l}-6 . \ddot{4} \\
-6.8\end{array}$ \\
\hline 2001-03 & $\begin{array}{l}\text { United Kingdom } \\
\text { Great Britain } \\
\text { England }\end{array}$ & $\begin{array}{l}75.9 \\
76.0 \\
76.2\end{array}$ & $\begin{array}{l}67.1 \\
67.2 \\
67.5\end{array}$ & $\begin{array}{l}66.9 \\
66.9 \\
67.2\end{array}$ & $\begin{array}{l}67.4 \\
67.4 \\
67.8\end{array}$ & $\begin{array}{l}88.4 \\
88.4 \\
88.5\end{array}$ & $\begin{array}{l}60.6 \\
60.7 \\
60.6\end{array}$ & $\begin{array}{l}60.3 \\
60.3 \\
60.3\end{array}$ & $\begin{array}{l}60.9 \\
61.0 \\
61.0\end{array}$ & $\begin{array}{l}79.9 \\
79.8 \\
79.6\end{array}$ & $\begin{array}{r}9.7 \\
9.7 \\
10.1\end{array}$ & $\begin{array}{l}-6.5 \\
-6.5 \\
-6.8\end{array}$ \\
\hline $2002-04$ & $\begin{array}{l}\text { United Kingdom } \\
\text { Great Britain } \\
\text { England }\end{array}$ & $\begin{array}{l}76.3 \\
76.3 \\
76.6\end{array}$ & $\begin{array}{l}67.6 \\
67.6 \\
68.0\end{array}$ & $\begin{array}{l}67.3 \\
67.4 \\
67.7\end{array}$ & $\begin{array}{l}67.8 \\
67.9 \\
68.2\end{array}$ & $\begin{array}{l}88.6 \\
88.6 \\
88.7\end{array}$ & $\begin{array}{l}60.8 \\
60.7 \\
61.0\end{array}$ & $\begin{array}{l}60.4 \\
60.4 \\
60.6\end{array}$ & $\begin{array}{l}61.1 \\
61.1 \\
61.4\end{array}$ & $\begin{array}{l}79.7 \\
79.6 \\
79.6\end{array}$ & $\begin{array}{l}10.0 \\
10.2 \\
10.2\end{array}$ & $\begin{array}{l}-6.8 \\
-6.9 \\
-7.0\end{array}$ \\
\hline $2003-05$ & $\begin{array}{l}\text { United Kingdom } \\
\text { Great Britain } \\
\text { England }\end{array}$ & $\begin{array}{l}76.6 \\
76.6 \\
76.9\end{array}$ & $\begin{array}{l}67.9 \\
68.0 \\
68.3\end{array}$ & $\begin{array}{l}67.7 \\
67.7 \\
68.0\end{array}$ & $\begin{array}{l}68.2 \\
68.2 \\
68.6\end{array}$ & $\begin{array}{l}88.7 \\
88.7 \\
88.8\end{array}$ & $\begin{array}{l}61.3 \\
61.2 \\
61.5\end{array}$ & $\begin{array}{l}60.9 \\
60.9 \\
61.1\end{array}$ & $\begin{array}{l}61.6 \\
61.6 \\
61.8\end{array}$ & $\begin{array}{l}80.0 \\
79.9 \\
79.9\end{array}$ & $\begin{array}{r}9.8 \\
9.9 \\
10.0\end{array}$ & $\begin{array}{l}-6.7 \\
-6.7 \\
-6.9\end{array}$ \\
\hline 2004-06 & $\begin{array}{l}\text { United Kingdom } \\
\text { Great Britain } \\
\text { England }\end{array}$ & $\begin{array}{l}76.9 \\
76.9 \\
77.2\end{array}$ & $\begin{array}{l}68.2 \\
68.2 \\
68.5\end{array}$ & $\begin{array}{l}67.9 \\
67.9 \\
68.2\end{array}$ & $\begin{array}{l}68.4 \\
68.5 \\
68.8\end{array}$ & $\begin{array}{l}88.7 \\
88.7 \\
88.7\end{array}$ & $\begin{array}{l}61.4 \\
61.4 \\
61.5\end{array}$ & $\begin{array}{l}61.0 \\
61.0 \\
61.1\end{array}$ & $\begin{array}{l}61.7 \\
61.8 \\
62.0\end{array}$ & $\begin{array}{l}79.8 \\
79.8 \\
79.7\end{array}$ & $\begin{array}{l}10.0 \\
10.0 \\
10.2\end{array}$ & $\begin{array}{l}-6.8 \\
-6.9 \\
-7.0\end{array}$ \\
\hline $\begin{array}{l}\text { At age } 65 \\
2000-02\end{array}$ & $\begin{array}{l}\text { United Kingdom } \\
\text { Great Britain } \\
\text { England }\end{array}$ & $\begin{array}{l}15.9 \\
15.9 \\
16.1\end{array}$ & $\begin{array}{l}11.9 \\
11.9 \\
12.0\end{array}$ & $\begin{array}{l}11.7 \\
11.7 \\
11.8\end{array}$ & $\begin{array}{l}12.1 \\
12.1 \\
12.2\end{array}$ & $\begin{array}{l}74.8 \\
74.8 \\
74.3\end{array}$ & $\begin{array}{l}9.3 \\
9.3\end{array}$ & $\begin{array}{l}9.1 \\
9.0\end{array}$ & $\begin{array}{l}9.0 \\
9.5\end{array}$ & $\begin{array}{l}58.0 \\
57.6\end{array}$ & $\begin{array}{l}21.8 \\
22.6\end{array}$ & $\begin{array}{l}-2 . \ddot{6} \\
-2.7\end{array}$ \\
\hline $2001-03$ & $\begin{array}{l}\text { United Kingdom } \\
\text { Great Britain } \\
\text { England }\end{array}$ & $\begin{array}{l}16.1 \\
16.1 \\
16.3\end{array}$ & $\begin{array}{l}12.0 \\
12.0 \\
12.2\end{array}$ & $\begin{array}{l}11.8 \\
11.8 \\
11.9\end{array}$ & $\begin{array}{l}12.2 \\
12.2 \\
12.4\end{array}$ & $\begin{array}{l}74.5 \\
74.6 \\
74.5\end{array}$ & $\begin{array}{l}9.3 \\
9.3 \\
9.3\end{array}$ & $\begin{array}{l}9.1 \\
9.0 \\
9.1\end{array}$ & $\begin{array}{l}9.5 \\
9.5 \\
9.6\end{array}$ & $\begin{array}{l}57.7 \\
57.6 \\
57.2\end{array}$ & $\begin{array}{l}22.5 \\
22.7 \\
23.3\end{array}$ & $\begin{array}{l}-2.7 \\
-2.7 \\
-2.8\end{array}$ \\
\hline $2002-04$ & $\begin{array}{l}\text { United Kingdom } \\
\text { Great Britain } \\
\text { England }\end{array}$ & $\begin{array}{l}16.4 \\
16.4 \\
16.5\end{array}$ & $\begin{array}{l}12.3 \\
12.3 \\
12.5\end{array}$ & $\begin{array}{l}12.1 \\
12.1 \\
12.3\end{array}$ & $\begin{array}{l}12.5 \\
12.5 \\
12.7\end{array}$ & $\begin{array}{l}74.9 \\
75.1 \\
75.6\end{array}$ & $\begin{array}{l}9.2 \\
9.4 \\
9.5\end{array}$ & $\begin{array}{l}9.0 \\
9.2 \\
9.3\end{array}$ & $\begin{array}{l}9.4 \\
9.7 \\
9.8\end{array}$ & $\begin{array}{l}56.2 \\
57.5 \\
57.8\end{array}$ & $\begin{array}{l}25.0 \\
23.5 \\
23.6\end{array}$ & $\begin{array}{l}-3.1 \\
-2.9 \\
-2.9\end{array}$ \\
\hline 2003-05 & $\begin{array}{l}\text { United Kingdom } \\
\text { Great Britain } \\
\text { England }\end{array}$ & $\begin{array}{l}16.6 \\
16.6 \\
16.8\end{array}$ & $\begin{array}{l}12.5 \\
12.5 \\
12.7\end{array}$ & $\begin{array}{l}12.4 \\
12.3 \\
12.5\end{array}$ & $\begin{array}{l}12.7 \\
12.7 \\
12.9\end{array}$ & $\begin{array}{l}75.5 \\
75.5 \\
75.5\end{array}$ & $\begin{array}{l}9.7 \\
9.7 \\
9.8\end{array}$ & $\begin{array}{l}9.5 \\
9.5 \\
9.5\end{array}$ & $\begin{array}{r}9.9 \\
9.9 \\
10.0\end{array}$ & $\begin{array}{l}58.4 \\
58.3 \\
58.0\end{array}$ & $\begin{array}{l}22.6 \\
22.9 \\
23.2\end{array}$ & $\begin{array}{l}-2.8 \\
-2.9 \\
-2.9\end{array}$ \\
\hline $2004-06$ & $\begin{array}{l}\text { United Kingdom } \\
\text { Great Britain } \\
\text { England }\end{array}$ & $\begin{array}{l}16.9 \\
16.9 \\
17.1\end{array}$ & $\begin{array}{l}12.8 \\
12.8 \\
12.9\end{array}$ & $\begin{array}{l}12.6 \\
12.6 \\
12.7\end{array}$ & $\begin{array}{l}13.0 \\
13.1 \\
13.2\end{array}$ & $\begin{array}{l}76.0 \\
76.0 \\
75.6\end{array}$ & $\begin{array}{l}9.9 \\
9.9 \\
9.9\end{array}$ & $\begin{array}{l}9.6 \\
9.6 \\
9.6\end{array}$ & $\begin{array}{l}10.1 \\
10.1 \\
10.2\end{array}$ & $\begin{array}{l}58.5 \\
58.3 \\
57.8\end{array}$ & $\begin{array}{l}23.1 \\
23.3 \\
23.6\end{array}$ & $\begin{array}{l}-3.0 \\
-3.0 \\
-3.1\end{array}$ \\
\hline
\end{tabular}

\section{Table 6} Healthy life expectancy at birth and age 65 for females, by country and original and simulated survey data, 2000-02 to 2004-06

\begin{tabular}{|c|c|c|c|c|c|c|c|c|c|c|c|c|}
\hline \multirow[b]{2}{*}{ Year } & \multirow[b]{2}{*}{ Country } & \multirow[b]{2}{*}{$\begin{array}{c}\text { Life } \\
\text { expectancy } \\
\text { (Years) }\end{array}$} & \multicolumn{4}{|c|}{ Original survey data } & \multicolumn{4}{|c|}{ Simulated survey data } & \multirow{2}{*}{$\begin{array}{c}\text { Decrease in } \\
\text { HLE between } \\
\text { original and } \\
\text { simulated } \\
\text { survey data } \\
\text { (per cent) }\end{array}$} & \multirow{2}{*}{$\begin{array}{c}\text { Difference } \\
\text { between } \\
\text { original anc } \\
\text { simulated } \\
\text { survey data } \\
\text { (Years) } \\
\end{array}$} \\
\hline & & & $\begin{array}{c}\text { Healthy life } \\
\text { expectancy } \\
\text { (Years) }\end{array}$ & $\begin{array}{c}\text { Lower } 95 \\
\text { per cent } \\
\text { confidence } \\
\text { interval }\end{array}$ & $\begin{array}{c}\text { Upper } 95 \\
\text { per cent } \\
\text { confidence } \\
\text { interval }\end{array}$ & $\begin{array}{c}\text { Proportion of } \\
\text { life in 'Good' } \\
\text { health } \\
\text { (per cent) }\end{array}$ & $\begin{array}{c}\text { Healthy life } \\
\text { expectancy } \\
\text { (Years) }\end{array}$ & $\begin{array}{c}\text { Lower } 95 \\
\text { per cent } \\
\text { confidence } \\
\text { interval } \\
\end{array}$ & $\begin{array}{c}\text { Upper } 95 \\
\text { per cent } \\
\text { confidence } \\
\text { interval } \\
\end{array}$ & $\begin{array}{c}\text { Proportion of } \\
\text { life in 'Good' } \\
\text { health } \\
\text { (per cent) }\end{array}$ & & \\
\hline $\begin{array}{l}\text { At birth } \\
2000-02\end{array}$ & $\begin{array}{l}\text { United Kingdom } \\
\text { Great Britain } \\
\text { England }\end{array}$ & $\begin{array}{l}80.4 \\
80.4 \\
80.6\end{array}$ & $\begin{array}{l}69.9 \\
69.9 \\
70.1\end{array}$ & $\begin{array}{l}69.6 \\
69.6 \\
69.8\end{array}$ & $\begin{array}{l}70.1 \\
70.2 \\
70.4\end{array}$ & $\begin{array}{l}86.9 \\
87.0 \\
87.0\end{array}$ & $\begin{array}{l}62.1 \\
62.0\end{array}$ & $\begin{array}{l}61.7 \\
61.6\end{array}$ & $\begin{array}{l}62.5 \\
62.4\end{array}$ & $\begin{array}{l}77.2 \\
76.9\end{array}$ & $\begin{array}{l}11.2 \\
11.6\end{array}$ & $\begin{array}{l}-7.8 \\
-8.1\end{array}$ \\
\hline $2001-03$ & $\begin{array}{l}\text { United Kingdom } \\
\text { Great Britain } \\
\text { England }\end{array}$ & $\begin{array}{l}80.5 \\
80.5 \\
80.7\end{array}$ & $\begin{array}{l}69.9 \\
69.9 \\
70.0\end{array}$ & $\begin{array}{l}69.6 \\
69.6 \\
69.7\end{array}$ & $\begin{array}{l}70.1 \\
70.2 \\
70.4\end{array}$ & $\begin{array}{l}86.8 \\
86.9 \\
86.8\end{array}$ & $\begin{array}{l}62.1 \\
61.9 \\
62.0\end{array}$ & $\begin{array}{l}61.8 \\
61.5 \\
61.6\end{array}$ & $\begin{array}{l}62.4 \\
62.3 \\
62.3\end{array}$ & $\begin{array}{l}77.1 \\
76.9 \\
76.8\end{array}$ & $\begin{array}{l}11.2 \\
11.5 \\
11.6\end{array}$ & $\begin{array}{l}-7.8 \\
-8.0 \\
-8.1\end{array}$ \\
\hline $2002-04$ & $\begin{array}{l}\text { United Kingdom } \\
\text { Great Britain } \\
\text { England }\end{array}$ & $\begin{array}{l}80.7 \\
80.7 \\
80.9\end{array}$ & $\begin{array}{l}70.1 \\
70.1 \\
70.2\end{array}$ & $\begin{array}{l}69.8 \\
69.8 \\
69.9\end{array}$ & $\begin{array}{l}70.3 \\
70.4 \\
70.6\end{array}$ & $\begin{array}{l}86.8 \\
86.9 \\
86.8\end{array}$ & $\begin{array}{l}62.3 \\
62.2 \\
62.2\end{array}$ & $\begin{array}{l}62.0 \\
61.8 \\
61.8\end{array}$ & $\begin{array}{l}62.7 \\
62.5 \\
62.6\end{array}$ & $\begin{array}{l}77.2 \\
77.0 \\
76.8\end{array}$ & $\begin{array}{l}11.0 \\
11.3 \\
11.5\end{array}$ & $\begin{array}{l}-7.7 \\
-7.9 \\
-8.1\end{array}$ \\
\hline 2003-05 & $\begin{array}{l}\text { United Kingdom } \\
\text { Great Britain } \\
\text { England }\end{array}$ & $\begin{array}{l}81.0 \\
81.0 \\
81.2\end{array}$ & $\begin{array}{l}70.3 \\
70.3 \\
70.6\end{array}$ & $\begin{array}{l}70.0 \\
70.0 \\
70.2\end{array}$ & $\begin{array}{l}70.5 \\
70.6 \\
70.9\end{array}$ & $\begin{array}{l}86.8 \\
86.8 \\
86.9\end{array}$ & $\begin{array}{l}62.8 \\
62.6 \\
62.7\end{array}$ & $\begin{array}{l}62.5 \\
62.3 \\
62.3\end{array}$ & $\begin{array}{l}63.1 \\
63.0 \\
63.1\end{array}$ & $\begin{array}{l}77.5 \\
77.3 \\
77.2\end{array}$ & $\begin{array}{l}10.7 \\
11.0 \\
11.1\end{array}$ & $\begin{array}{l}-7.5 \\
-7.7 \\
-7.9\end{array}$ \\
\hline $2004-06$ & $\begin{array}{l}\text { United Kingdom } \\
\text { Great Britain } \\
\text { England }\end{array}$ & $\begin{array}{l}81.3 \\
81.3 \\
81.5\end{array}$ & $\begin{array}{l}70.4 \\
70.5 \\
70.7\end{array}$ & $\begin{array}{l}70.1 \\
70.1 \\
70.3\end{array}$ & $\begin{array}{l}70.7 \\
70.8 \\
71.0\end{array}$ & $\begin{array}{l}86.6 \\
86.7 \\
86.7\end{array}$ & $\begin{array}{l}62.7 \\
62.6 \\
62.9\end{array}$ & $\begin{array}{l}62.4 \\
62.2 \\
62.5\end{array}$ & $\begin{array}{l}63.1 \\
63.0 \\
63.3\end{array}$ & $\begin{array}{l}77.2 \\
76.9 \\
77.2\end{array}$ & $\begin{array}{l}10.9 \\
11.2 \\
11.0\end{array}$ & $\begin{array}{l}-7.7 \\
-7.9 \\
-7.8\end{array}$ \\
\hline $\begin{array}{l}\text { At age } 65 \\
2000-02\end{array}$ & $\begin{array}{l}\text { United Kingdom } \\
\text { Great Britain } \\
\text { England }\end{array}$ & $\begin{array}{l}19.0 \\
19.0 \\
19.2\end{array}$ & $\begin{array}{l}14.0 \\
14.0 \\
14.2\end{array}$ & $\begin{array}{l}13.8 \\
13.8 \\
14.0\end{array}$ & $\begin{array}{l}14.2 \\
14.3 \\
14.4\end{array}$ & $\begin{array}{l}73.7 \\
73.9 \\
74.0\end{array}$ & $\begin{array}{l}10.5 \\
10.5\end{array}$ & $\begin{array}{l}10.2 \\
10.2\end{array}$ & $\begin{array}{l}10.7 \\
10.8\end{array}$ & $\begin{array}{l}55.1 \\
54.7\end{array}$ & $\begin{array}{l}25.4 \\
26.1\end{array}$ & $\begin{array}{l}-3.6 \\
-3.7\end{array}$ \\
\hline 2001-03 & $\begin{array}{l}\text { United Kingdom } \\
\text { Great Britain } \\
\text { England }\end{array}$ & $\begin{array}{l}19.1 \\
19.1 \\
19.2\end{array}$ & $\begin{array}{l}14.0 \\
14.1 \\
14.2\end{array}$ & $\begin{array}{l}13.9 \\
13.9 \\
13.9\end{array}$ & $\begin{array}{l}14.2 \\
14.3 \\
14.4\end{array}$ & $\begin{array}{l}73.5 \\
73.6 \\
73.7\end{array}$ & $\begin{array}{l}10.5 \\
10.4 \\
10.4\end{array}$ & $\begin{array}{l}10.3 \\
10.1 \\
10.2\end{array}$ & $\begin{array}{l}10.7 \\
10.6 \\
10.7\end{array}$ & $\begin{array}{l}54.8 \\
54.2 \\
54.4\end{array}$ & $\begin{array}{l}25.4 \\
26.4 \\
26.2\end{array}$ & $\begin{array}{l}-3.6 \\
-3.7 \\
-3.7\end{array}$ \\
\hline $2002-04$ & $\begin{array}{l}\text { United Kingdom } \\
\text { Great Britain } \\
\text { England }\end{array}$ & $\begin{array}{l}19.3 \\
19.3 \\
19.4\end{array}$ & $\begin{array}{l}14.3 \\
14.3 \\
14.4\end{array}$ & $\begin{array}{l}14.1 \\
14.1 \\
14.2\end{array}$ & $\begin{array}{l}14.5 \\
14.5 \\
14.6\end{array}$ & $\begin{array}{l}73.9 \\
74.0 \\
74.2\end{array}$ & $\begin{array}{l}10.7 \\
10.6 \\
10.6\end{array}$ & $\begin{array}{l}10.5 \\
10.3 \\
10.4\end{array}$ & $\begin{array}{l}10.9 \\
10.8 \\
10.9\end{array}$ & $\begin{array}{l}55.4 \\
54.8 \\
54.8\end{array}$ & $\begin{array}{l}25.0 \\
25.9 \\
26.2\end{array}$ & $\begin{array}{l}-3.6 \\
-3.7 \\
-3.8\end{array}$ \\
\hline 2003-05 & $\begin{array}{l}\text { United Kingdom } \\
\text { Great Britain } \\
\text { England }\end{array}$ & $\begin{array}{l}19.4 \\
19.4 \\
19.6\end{array}$ & $\begin{array}{l}14.5 \\
14.5 \\
14.6\end{array}$ & $\begin{array}{l}14.3 \\
14.3 \\
14.4\end{array}$ & $\begin{array}{l}14.7 \\
14.7 \\
14.9\end{array}$ & $\begin{array}{l}74.6 \\
74.7 \\
74.7\end{array}$ & $\begin{array}{l}10.9 \\
10.8 \\
10.9\end{array}$ & $\begin{array}{l}10.7 \\
10.6 \\
10.6\end{array}$ & $\begin{array}{l}11.2 \\
11.1 \\
11.2\end{array}$ & $\begin{array}{l}56.4 \\
55.8 \\
55.6\end{array}$ & $\begin{array}{l}24.4 \\
25.3 \\
25.6\end{array}$ & $\begin{array}{l}-3.5 \\
-3.7 \\
-3.8\end{array}$ \\
\hline $2004-06$ & $\begin{array}{l}\text { United Kingdom } \\
\text { Great Britain } \\
\text { England }\end{array}$ & $\begin{array}{l}19.7 \\
19.7 \\
19.9\end{array}$ & $\begin{array}{l}14.5 \\
14.5 \\
14.7\end{array}$ & $\begin{array}{l}14.3 \\
14.3 \\
14.4\end{array}$ & $\begin{array}{l}14.7 \\
14.8 \\
14.9\end{array}$ & $\begin{array}{l}73.7 \\
73.8 \\
73.7\end{array}$ & $\begin{array}{l}11.0 \\
10.9 \\
11.0\end{array}$ & $\begin{array}{l}10.7 \\
10.6 \\
10.7\end{array}$ & $\begin{array}{l}11.2 \\
11.1 \\
11.3\end{array}$ & $\begin{array}{l}55.7 \\
55.1 \\
55.1\end{array}$ & $\begin{array}{l}24.4 \\
25.3 \\
25.3\end{array}$ & $\begin{array}{l}-3.5 \\
-3.7 \\
-3.7\end{array}$ \\
\hline
\end{tabular}




\section{General health prevalence}

The analysis of responses to the general health questions in the GHS and CHS 2005-06 suggest 9 per cent fewer people will be categorised in 'Good' health under the SILC general health question. There were fewer females categorised in 'Good' health than males, regardless of question; this finding suggests the presence of gender bias in the reporting of general health in response to different questions is unlikely.

Comparisons of self-reported health states and LLSI showed that those defined in 'Good' health under the SILC general health question were significantly less likely to report a limiting illness or disability than those defined in 'Good' health from the original question. This finding demonstrates the EU definition of 'Good' health has a stronger relationship with functional health status and thereby service need and fitness for work beyond the state pension age.

\section{Survey response translation}

The translation of self-reported health states from the original to the SILC question showed sample members to generally report a more favourable health state in response to the latter question. However, the pattern of more favourable reporting of health status in response to the SILC question did not translate into an improvement in the prevalence of 'Good' health classified under the EU definition. This arises because the EU definition of 'Good' health is more restrictive, only including the responses Very good and Good. The exclusion of the response category Fair in the classification of individuals to the dichotomised health status category 'Good' is supported by the relatively high prevalence of LLSI (that is between 50.4 and 53.8 per cent for the UK, GB and England) reported by those classifying their general health as Fair.

\section{Simulated general health prevalence}

The translation of responses from the original to the SILC general health question informed the development of factors to adjust historic survey data. These were used to simulate the use of the SILC question on published estimates of HLE, and thereby provide an insight into the likely impact of using this question in the future reporting of HLE in the UK. In the first instance, the prevalence of 'Good' health calculated from simulated GHS data (that is simulating the EU definition of health status from the SILC question) was compared to original GHS data, and also HSE data in a time series starting in 1991-93. In analyses using original GHS data and the existing definition of dichotomised health, there was a higher prevalence of 'Good' health in both men and women, compared with either the HSE or simulated GHS data over the same period; however, no differences in the prevalence of 'Good' health were detected between the HSE and the simulated GHS data. The uniformity in the prevalence of 'Good' health calculated using HSE and simulated GHS data between 1991-93 and 2004-06 supports the consistency observed between the SILC question in the GHS and the equivalent question in the HSE calculated for 2005-06. This suggests the method developed to adjust survey data by factors calculated from the translation of health states between the original and SILC questions in 2005-06 is reliable and appropriate for use in the simulation of historic survey data.

Between 1980-82 and 2004-06 the average prevalence of 'Good' health calculated from simulated data was some 11 per cent lower than the prevalence derived from original data (Figures 4 and 5). This difference in prevalence is somewhat greater than the 9 per cent reduction observed between the SILC general health question and the original general health question in 2005-06 (Table 2). This small discrepancy is partly a result of the different age range encompassed in each analysis: the actual 2005-06 data included the total population from birth; whereas the comparison of historic and simulated data between 1980-82 and 2004-06 was restricted to those aged 16 years of age and above. There was a high degree of consistency in the prevalence of 'Good' health over time between 1980-82 and 2004-06, particularly for men. These findings imply that the prevalence of 'Good' health in the population is likely to be around 9 to 11.5 per cent lower using the SILC general health question in future years.

\section{Simulated healthy life expectancy}

The likely impact of the reduction in the proportion of the population in 'Good' health on UK estimates of HLE reported by ONS since 2000-02 was investigated through simulation. Adjustment factors were further refined by taking account of the influence of the socio-economic position of the household reference person. The simulated estimates of HLE for the UK, GB and England between 2000-02 and 2004-06 were significantly lower than published estimates: at birth, around 7 years $(10$ per cent) for men and around 8 years (11 per cent) for women; at age 65 , around 3 years ( 22 per cent) for men and around 3.5 years ( 25 per cent) for women.

A greater proportional loss of years spent in 'Good' health at older ages is to be expected using the SILC question because self-reported health is worse at older ages than at younger ages. Analysis of the translation of responses from the original to the SILC question shows most survey respondents report an improved health rating in response to the SILC general health question; however, the impact of these translations on classification to the EU definition varied by age. Specifically, although older people reported an improved health rating in response to the SILC question, this was insufficient to classify them to the dichotomised 'Good' health category.

The underlying trend in HLE over the five-year period 2000-02 to 2004-06 was of increasing years spent in 'Good' health for men and women using both the original and simulated general health questions. However, there were slight differences in the rate of change over this period depending on the question asked. For men, increases in HLE at birth and at age 65 were smaller in the simulated estimates compared with the original estimates in both GB and England; however, for women, increases over time were smaller in GB but equivalent or greater in England in the simulated compared to original estimates. Consequently, there were also slight differences between original and simulated estimates in the change over time in the proportion of life spent in 'Good' health. Over time, the proportion of life in 'Good' health changed less for simulated compared to original estimates of HLE, slightly reducing the magnitude of the overlying trend of increased proportions of life in 'Good' health for men at birth and at age 65. For women, the picture is more complex: in England at birth and at age 65 , females experienced a slight increase in the proportion of life spent in 'Good' health in simulated estimates between 2000-02 and 2004-06, compared with a slight reduction over this period in original estimates. At birth and at age 65 in GB differences were negligible $(\leq 0.1$ per cent).

If current trends in HLE persist, adoption of the SILC general health question may lead to a slight contraction in the rate of increase in HLE observed under the original general health question in men. For women in England, rates of improvement in HLE appear likely to increase slightly after adoption of the SILC general health question than would be the case under the original question.

\section{Conclusions}

1. The original general health question ceased to be included in the GHS and CHS in 2008; consequently, only the SILC question will be available for analysis from 2008 onwards. The ONS will report estimates of HLE based on original and SILC general health 
questions for the period 2005-07 after which estimates will be based exclusively on the SILC question.

2. Adoption of the SILC general health question will facilitate easier comparison with EU member states, particularly in terms of the prevalence of health states. There will remain, however, some discrepancies in HLE outputs since UK estimates are partly based on the inclusion of the communal establishment population derived from the 2001 Census.

3. Adoption of the harmonised SILC general health question and the European definition of 'Good' health will cause a marked, significant reduction in the prevalence of 'Good' health and estimates of HLE for men and women at birth and at age 65 .

4. The revised measure is a more robust indicator of functional health status as measured by limiting long-standing illness.

5. If the current trend over time of increasing HLE persists, estimates derived using the SILC general health question are likely to increase at a slightly slower rate for men and an equivalent or marginally faster rate for women than would be the case using the original general health question. These differences are negligible and unlikely to lead to a notable change in the underlying pattern of improvement in HLE observed since 2000-02.

\section{Key findings}

- Comparison of responses to original and SILC general health questions gives a good indication of the extent of the impact of question change on the prevalence of 'Good' health and HLE in the population reported by ONS

- Possible confounding effects of concurrent general health questions are minimal

- Adoption of the SILC general health question will result in a significant reduction in the proportion of the population considered in 'Good' health

- The SILC general health question better reflects functional health status

- Estimates of HLE are likely to fall significantly with adoption of the SILC general health question

- Trends in increasing HLE over time are unlikely to be significantly affected by the change in general health question

\section{References}

1. Robine J-M, Jagger C and The Euro-REVES Group (2003) 'Creating a coherent set of indicators to monitor health across Europe. The Euro-REVES project', European Journal of Public Health $\mathbf{1 3}$ (supplement 1), 6-14.

2. de Bruin A, Picavet H S V and Nossikov A (eds) (1996) 'Health interview surveys. Towards international harmonisation', World Health Organisation Regional publications, European Series, no. 58.

3. Office for National Statistics Health expectancies at birth \& at age 65 in the United Kingdom. Available on the Office for National Statistics website: www.statistics.gov.uk/statbase/Product.asp?vlnk=12964

4. Organisation for Economic Co-operation and Development (2002) OECD health data 2002: a Comparative Analysis of 30 countries, Organisation for Economic Co-operation and Development: Paris.

5. Bajekal M and Purdon S (2002) 'Healthy life expectancy at Health Authority level: comparing estimates from the General Household Survey and the Health Survey for England', Health Statistics Quarterly 16, 25-37. Available on the Office for National Statistics website at: www.statistics.gov.uk/statbase/Product.asp?vlnk $=6725$

6. Breakwell C and Bajekal M (2005) 'Review of sources and methods to monitor healthy life expectancy', Health Statistics Quarterly 26, 17-22. Available on the Office for National Statistics website at: www.statistics.gov.uk/statbase/Product.asp?vlnk $=6725$

7. Office for National Statistics (2008) 'Report: Health Expectancies in the United Kingdom, 2004-06', Health Statistics Quarterly 40, 77-80. Available on the Office for National Statistics website at: www.statistics.gov.uk/statbase/Product.asp?vlnk $=6725$

8. Bowling A and Windsor J (2008) 'The effects of question order and response-choice on self-rated health status in the English Longitudinal Study of Ageing (ELSA)', Journal of Epidemiology and Community Health 62, 81-85.

9. Crossley T F and Kennedy S (2002) 'The reliability of self assessed health status', Journal of Health Economics 21, 643-58.

10. Bone M R, Bebbington A C, Jagger C et al (1995) Health expectancy and its uses, Her Majesty's Stationery Office: London.

11. Power C, Matthews S and Manor O (1998) 'Inequalities in self-rated health: explanations from different stages of life', The Lancet 351, 1009-14.

12. White I R, Blane D, Morris J N and Mourouga P (1999) 'Educational attainment, deprivation-affluence and self-reported health in Britain: a cross sectional study', Journal of Epidemiology and Community Health 53, 535-41.

13. Hyde M, Jakub H, Melchior M et al (2006) 'Comparison of the effects of low childhood socio-economic position and low adulthood socioeconomic position on self-rated health in four European studies', Journal of Epidemiology and Community Health 60, 882-86.

14. Office for National Statistics The National Statistics Socio-economic Classification (NS-SEC), available on the Office for National Statistics website at: www.statistics.gov.uk/methods_quality/ns_sec/default.asp

15. Kalton G and Schuman H (1982) 'The effect of the question on survey responses: A review', Journal of the Royal Statistical Society Series A 145, 42-73. 


\section{Appendix}

\begin{tabular}{|c|c|c|c|}
\hline Table A1 & \multicolumn{3}{|c|}{ Adjustment factors for adult males } \\
\hline \multicolumn{4}{|l|}{ England } \\
\hline \multirow[b]{2}{*}{$\begin{array}{l}\text { Age } \\
\text { group }\end{array}$} & \multicolumn{3}{|c|}{ Adjustment factor } \\
\hline & $\begin{array}{l}\alpha^{1} \text { Good to Fair/Bad/Very } \\
\text { bad health (per cent) }\end{array}$ & $\begin{array}{l}\beta^{1} \text { Fairly good to Good/Very } \\
\text { good health (per cent) }\end{array}$ & $\begin{array}{l}\gamma^{1} \text { Not good to Good/Very } \\
\text { good health (per cent) }\end{array}$ \\
\hline $16-19$ & 0.8 & 79.1 & 20.0 \\
\hline $20-24$ & 1.6 & 70.4 & 23.8 \\
\hline $25-29$ & 3.0 & 76.9 & 24.4 \\
\hline 30-34 & 2.8 & 69.5 & 16.1 \\
\hline $35-39$ & 1.7 & 68.9 & 18.8 \\
\hline 40-44 & 1.9 & 68.0 & 18.3 \\
\hline $45-49$ & 3.1 & 64.3 & 17.4 \\
\hline $50-54$ & 4.3 & 61.9 & 9.9 \\
\hline $55-59$ & 2.1 & 53.4 & 9.6 \\
\hline 60-64 & 4.5 & 52.5 & 12.7 \\
\hline $65-69$ & 5.0 & 53.6 & 10.3 \\
\hline 70-74 & 5.2 & 53.0 & 8.5 \\
\hline 75-79 & 3.3 & 53.6 & 9.9 \\
\hline 80-84 & 6.7 & 40.4 & 9.4 \\
\hline $85+$ & 5.2 & 50.0 & 10.9 \\
\hline Total & 2.9 & 60.0 & 12.7 \\
\hline
\end{tabular}

1 See Box Two.

\section{Table A3}

Adjustment factors for adult males

Great Britain

\begin{tabular}{c|c|c|c}
\hline \multirow{2}{*}{$\begin{array}{c}\text { Age } \\
\text { group }\end{array}$} & $\begin{array}{c}\mid c \\
\alpha^{1} \text { Good to Fair/Bad/Very } \\
\text { bad health (per cent) }\end{array}$ & $\begin{array}{c}\beta^{1} \text { Fairly good to Good/Very } \\
\text { good health (per cent) }\end{array}$ & $\begin{array}{c}\gamma^{1} \text { Not good to Good/Very } \\
\text { good health (per cent) }\end{array}$ \\
\cline { 2 - 4 } $16-19$ & 0.9 & 78.7 & 20.8 \\
$20-24$ & 1.5 & 71.7 & 26.9 \\
$25-29$ & 2.8 & 74.8 & 25.0 \\
$30-34$ & 2.5 & 68.9 & 13.8 \\
$35-39$ & 1.6 & 69.0 & 17.8 \\
$40-44$ & 1.9 & 68.1 & 17.9 \\
$45-49$ & 3.1 & 62.2 & 18.8 \\
$50-54$ & 3.9 & 60.2 & 9.2 \\
$55-59$ & 2.2 & 53.6 & 8.2 \\
$60-64$ & 4.4 & 52.1 & 10.8 \\
$65-69$ & 4.2 & 55.5 & 10.5 \\
$70-74$ & 4.5 & 52.2 & 7.5 \\
$75-79$ & 5.3 & 53.2 & 9.2 \\
$80-84$ & 5.9 & 42.3 & 9.3 \\
$85+$ & 4.7 & 54.2 & 9.8 \\
Total & 2.7 & 59.8 & 12.1 \\
\hline 5 & & &
\end{tabular}

1 See Box Two.

Table A5

Variables associated with increased risk of reporting 'Not good' health

\begin{tabular}{l|r|r|r|r}
\hline \multicolumn{1}{c|}{ Variable } & Odds ratio & $\begin{array}{c}\text { Lower 95 } \\
\text { per cent } \\
\text { confidence } \\
\text { interval }\end{array}$ & $\begin{array}{c}\text { Upper 95 } \\
\text { per cent } \\
\text { confidence } \\
\text { interval }\end{array}$ & p-value \\
\hline Age (year-on-year increase) & 1.035 & 1.033 & 1.036 & $<0.000$ \\
Male & 1.000 & $:$ & $:$ & $:$ \\
Female & 1.131 & 1.054 & 1.215 & $<0.001$ \\
HRP NS-SEC 1 - managerial and professional & & & & $:$ \\
OcCupations & 1.000 & $:$ & $:$ & $:$ \\
HRP NS-SEC 2 - Intermediate occupations & 1.381 & 1.247 & 1.529 & $<0.000$ \\
HRP NS-SEC 3 - Routine and manual occupations & 1.954 & 1.803 & 2.119 & $<0.000$ \\
\hline
\end{tabular}

\section{Table A2}

Adjustment factors for adult females

England

\begin{tabular}{l|c|c|c}
\hline \multirow{2}{*}{$\begin{array}{c}\text { Age } \\
\text { group }\end{array}$} & $\begin{array}{c}\alpha^{1} \text { Good to Fair/Bad/Very } \\
\text { bad health (per cent) }\end{array}$ & $\begin{array}{c}\beta^{1} \text { Fairly good to Good/Nery } \\
\text { good health (per cent) }\end{array}$ & $\begin{array}{c}\gamma^{1} \text { Not good to Good/Very } \\
\text { good health (per cent) }\end{array}$ \\
\cline { 2 - 4 } $16-19$ & 1.0 & 73.5 & 33.3 \\
$20-24$ & 2.8 & 69.4 & 15.1 \\
$25-29$ & 2.3 & 65.8 & 25.4 \\
$30-34$ & 1.7 & 68.0 & 19.1 \\
$35-39$ & 1.1 & 67.7 & 21.5 \\
$40-44$ & 1.8 & 66.7 & 15.4 \\
$45-49$ & 2.5 & 65.5 & 11.3 \\
$50-54$ & 1.0 & 58.4 & 10.7 \\
$55-59$ & 2.4 & 54.3 & 12.3 \\
$60-64$ & 4.8 & 53.8 & 10.7 \\
$65-69$ & 2.9 & 52.4 & 8.6 \\
$70-74$ & 2.0 & 47.2 & 10.2 \\
$75-79$ & 2.4 & 47.6 & 5.3 \\
$80-84$ & 2.8 & 38.7 & 7.3 \\
$85+$ & 6.6 & 43.6 & 3.4 \\
Total & 2.2 & 58.0 & 12.0 \\
\hline 1520 & & & \\
\hline
\end{tabular}

1 See Box Two.

\section{Table A4}

Adjustment factors for adult females

Great Britain

\begin{tabular}{c|c|c|c}
\hline \multirow{2}{*}{$\begin{array}{c}\text { Age } \\
\text { group }\end{array}$} & \begin{tabular}{c}
\multicolumn{3}{|c}{ Adjustment factor } \\
\cline { 2 - 4 } bad health (per cent)
\end{tabular} & $\begin{array}{c}\beta^{1} \text { Fairly good to Good/Nery } \\
\text { good health (per cent) }\end{array}$ & $\begin{array}{c}\gamma^{1} \text { Not good to Good/Very } \\
\text { good health (per cent) }\end{array}$ \\
\hline $16-19$ & 0.8 & 74.2 & 33.3 \\
$20-24$ & 2.8 & 70.2 & 15.2 \\
$25-29$ & 2.2 & 69.0 & 25.0 \\
$30-34$ & 2.0 & 68.9 & 20.2 \\
$35-39$ & 1.1 & 68.0 & 19.8 \\
$40-44$ & 1.7 & 67.6 & 15.4 \\
$45-49$ & 2.3 & 64.4 & 10.7 \\
$50-54$ & 1.4 & 57.3 & 10.2 \\
$55-59$ & 2.6 & 52.6 & 12.2 \\
$60-64$ & 4.0 & 54.3 & 8.9 \\
$65-69$ & 2.4 & 51.8 & 7.9 \\
$70-74$ & 1.6 & 45.7 & 8.9 \\
$75-79$ & 2.6 & 49.5 & 5.3 \\
$80-84$ & 3.1 & 38.3 & 7.1 \\
$85+$ & 5.1 & 43.6 & 3.7 \\
Total & 2.1 & 58.0 & 11.4 \\
\hline 1500 & & &
\end{tabular}

1 See Box Two. 


\begin{tabular}{|c|c|c|c|c|c|c|c|c|c|}
\hline \multirow[b]{2}{*}{ Age group } & \multicolumn{3}{|c|}{ Class 1 HRP NS-SEC } & \multicolumn{3}{|c|}{ Class 2 HRP NS-SEC } & \multicolumn{3}{|c|}{ Class 3 HRP NS-SEC } \\
\hline & $\begin{array}{c}\alpha^{1} \text { Good to Fair/ } \\
\text { Bad/Very bad } \\
\text { health (per cent) }\end{array}$ & $\begin{array}{l}\beta^{1} \text { Fairly good to } \\
\text { Good/Very good } \\
\text { health (per cent) }\end{array}$ & $\begin{array}{l}\gamma^{1} \text { Not good to } \\
\text { Good/Very good } \\
\text { health (per cent) }\end{array}$ & $\begin{array}{c}\alpha^{1} \text { Good to Fair/ } \\
\text { Bad/Very bad } \\
\text { health (per cent) }\end{array}$ & $\begin{array}{l}\beta^{1} \text { Fairly good to } \\
\text { Good/Very good } \\
\text { health (per cent) }\end{array}$ & $\begin{array}{l}\gamma^{1} \text { Not good to } \\
\text { Good/Very good } \\
\text { health (per cent) }\end{array}$ & $\begin{array}{c}\alpha^{1} \text { Good to Fair/ } \\
\text { Bad/Very bad } \\
\text { health (per cent) }\end{array}$ & $\begin{array}{l}\beta^{1} \text { Fairly good to } \\
\text { Good/Very good } \\
\text { health (per cent) }\end{array}$ & $\begin{array}{l}\gamma^{1} \text { Not good to } \\
\text { Good/Very good } \\
\text { health (per cent) }\end{array}$ \\
\hline $0-4$ & - & 70.3 & 25.0 & 2.0 & 71.7 & - & 0.6 & 70.1 & 13.3 \\
\hline $5-9$ & 0.9 & 67.4 & 16.7 & 0.5 & 88.5 & - & 0.7 & 63.3 & 15.4 \\
\hline 10-14 & 0.7 & 68.0 & 25.0 & - & 70.0 & 42.9 & 1.9 & 63.9 & 9.1 \\
\hline 15-19 & - & 80.0 & 20.0 & 2.2 & 85.7 & 28.6 & 0.4 & 69.0 & 21.4 \\
\hline $20-24$ & 1.7 & 78.1 & 22.2 & 1.4 & 73.3 & - & 1.7 & 66.7 & 30.8 \\
\hline $25-29$ & 2.4 & 75.4 & 36.4 & 3.1 & 66.7 & 28.6 & 1.4 & 76.0 & 20.0 \\
\hline $30-34$ & 1.9 & 76.2 & 20.0 & 2.9 & 68.8 & 16.7 & 3.0 & 70.2 & 11.9 \\
\hline $35-39$ & 1.8 & 74.8 & 29.2 & 0.8 & 64.9 & 6.3 & 1.9 & 59.7 & 14.3 \\
\hline $40-44$ & 0.5 & 74.0 & 12.5 & 4.5 & 60.0 & 22.2 & 2.3 & 66.0 & 19.5 \\
\hline $45-49$ & 3.1 & 59.1 & 29.4 & 4.0 & 70.0 & 8.3 & 2.8 & 61.8 & 12.5 \\
\hline $50-54$ & 2.5 & 62.5 & 12.5 & 2.0 & 61.0 & 11.8 & 6.5 & 61.6 & 6.8 \\
\hline $55-59$ & 2.8 & 55.2 & 13.5 & 1.7 & 56.5 & 4.7 & 1.1 & 47.8 & 5.1 \\
\hline $60-64$ & 2.6 & 60.6 & 15.4 & 5.3 & 64.2 & 2.4 & 3.8 & 43.1 & 11.0 \\
\hline $65-69$ & 5.0 & 60.9 & 19.5 & 2.6 & 60.0 & 3.3 & 3.7 & 51.0 & 8.9 \\
\hline $70-74$ & 4.2 & 53.5 & 4.3 & 2.2 & 62.5 & 15.4 & 5.6 & 49.2 & 5.6 \\
\hline 75-79 & 1.3 & 56.3 & 7.1 & 3.7 & 52.3 & 4.8 & 10.9 & 50.6 & 10.7 \\
\hline $80-84$ & 6.4 & 43.4 & 15.2 & 5.0 & 58.8 & 7.1 & 4.9 & 38.0 & 8.2 \\
\hline $85+$ & 3.2 & 63.6 & 10.0 & 10.0 & 50.0 & 8.3 & 4.0 & 51.3 & 8.7 \\
\hline Total & 1.7 & 64.3 & 16.0 & 2.2 & 64.6 & 9.1 & 2.3 & 56.9 & 10.5 \\
\hline
\end{tabular}

1 See Box Two.

Table A7

United Kingdom

\section{Adjustment factors for females by condensed HRP NS-SEC}

\begin{tabular}{|c|c|c|c|c|c|c|c|c|c|}
\hline \multirow[b]{2}{*}{ Age group } & \multicolumn{3}{|c|}{ Class 1 HRP NS-SEC } & \multicolumn{3}{|c|}{ Class 2 HRP NS-SEC } & \multicolumn{3}{|c|}{ Class 3 HRP NS-SEC } \\
\hline & $\begin{array}{c}\alpha^{1} \text { Good to Fair/ } \\
\text { Bad/Very bad } \\
\text { health (per cent) }\end{array}$ & $\begin{array}{l}\beta^{1} \text { Fairly good to } \\
\text { Good/Very good } \\
\text { health (per cent) }\end{array}$ & $\begin{array}{l}\gamma^{1} \text { Not good to } \\
\text { Good/Very good } \\
\text { health (per cent) }\end{array}$ & $\begin{array}{c}\alpha^{1} \text { Good to Fair/ } \\
\text { Bad/Very bad } \\
\text { health (per cent) }\end{array}$ & $\begin{array}{l}\beta^{1} \text { Fairly good to } \\
\text { Good/Very good } \\
\text { health (per cent) }\end{array}$ & $\begin{array}{l}\gamma^{1} \text { Not good to } \\
\text { Good/Very good } \\
\text { health (per cent) }\end{array}$ & $\begin{array}{c}\alpha^{1} \text { Good to Fair/ } \\
\text { Bad/Very bad } \\
\text { health (per cent) }\end{array}$ & $\begin{array}{l}\beta^{1} \text { Fairly good to } \\
\text { Good/Very good } \\
\text { health (per cent) }\end{array}$ & $\begin{array}{l}\gamma^{1} \text { Not good to } \\
\text { Good/Very good } \\
\text { health (per cent) }\end{array}$ \\
\hline $0-4$ & 0.5 & 76.9 & 28.6 & - & 76.9 & - & 0.3 & 74.6 & 11.8 \\
\hline $5-9$ & 1.1 & 74.0 & 22.2 & 0.6 & 85.7 & - & 0.9 & 66.1 & 13.3 \\
\hline $10-14$ & 0.2 & 64.8 & 33.3 & - & 74.1 & - & - & 62.3 & - \\
\hline $15-19$ & 0.7 & 72.5 & 25.0 & 1.5 & 90.3 & - & 0.8 & 78.0 & 12.5 \\
\hline $20-24$ & 2.1 & 69.2 & 12.5 & 2.1 & 71.1 & 6.7 & 2.6 & 71.4 & 21.2 \\
\hline $25-29$ & 2.9 & 67.5 & 23.5 & 1.0 & 73.9 & 15.4 & 2.2 & 70.7 & 26.3 \\
\hline $30-34$ & 0.9 & 75.3 & 35.1 & 2.3 & 77.0 & 27.8 & 3.4 & 64.6 & 15.2 \\
\hline $35-39$ & 0.7 & 65.3 & 29.5 & 1.2 & 74.1 & 14.8 & 1.3 & 69.3 & 13.8 \\
\hline $40-44$ & 2.1 & 70.1 & 25.9 & 1.2 & 71.2 & 13.8 & 0.8 & 64.6 & 10.1 \\
\hline $45-49$ & 2.0 & 71.5 & 16.7 & 1.4 & 54.5 & 10.7 & 2.9 & 58.1 & 7.1 \\
\hline $50-54$ & 1.0 & 67.3 & 17.0 & 3.3 & 52.2 & 10.7 & 1.6 & 57.5 & 4.8 \\
\hline $55-59$ & 2.7 & 52.4 & 16.7 & 2.4 & 58.3 & 10.6 & 2.5 & 52.9 & 10.3 \\
\hline $60-64$ & 2.2 & 61.0 & 18.2 & 4.5 & 58.5 & 11.9 & 4.6 & 50.3 & 4.0 \\
\hline $65-69$ & 2.9 & 55.7 & 9.8 & 1.1 & 61.6 & 6.3 & 1.4 & 47.1 & 8.5 \\
\hline $70-74$ & - & 48.5 & 10.2 & - & 50.8 & 2.9 & 3.7 & 46.7 & 8.5 \\
\hline $75-79$ & 2.7 & 58.1 & 5.5 & 4.7 & 51.8 & 9.1 & 2.2 & 48.3 & 5.8 \\
\hline $80-84$ & 2.5 & 40.7 & 3.8 & - & 45.6 & 16.2 & 4.9 & 28.9 & 4.9 \\
\hline $85+$ & 4.3 & 60.9 & 3.4 & 9.5 & 40.9 & 4.5 & - & 40.3 & 1.8 \\
\hline Total & 1.4 & 63.9 & 17.0 & 1.5 & 63.0 & 10.7 & 1.7 & 56.3 & 8.8 \\
\hline
\end{tabular}

1 See Box Two. 


\begin{tabular}{|c|c|c|c|c|c|c|c|c|c|}
\hline \multirow{2}{*}{$\begin{array}{c}\text { Table A8 } \\
\text { Great Britain }\end{array}$} & \multicolumn{9}{|c|}{ Adjustment factors for males by condensed HRP NS-SEC } \\
\hline & & & & & & & & & \\
\hline \multirow[b]{2}{*}{ Age group } & \multicolumn{3}{|c|}{ Class 1 HRP NS-SEC } & \multicolumn{3}{|c|}{ Class 2 HRP NS-SEC } & \multicolumn{3}{|c|}{ Class 3 HRP NS-SEC } \\
\hline & $\begin{array}{l}\alpha^{1} \text { Good to Fair/ } \\
\text { Bad/Very bad } \\
\text { health (per cent) }\end{array}$ & $\begin{array}{l}\beta^{1} \text { Fairly good to } \\
\text { Good/Very good } \\
\text { health (per cent) }\end{array}$ & $\begin{array}{l}\gamma^{1} \text { Not good to } \\
\text { Good/Very good } \\
\text { health (per cent) }\end{array}$ & $\begin{array}{l}\alpha^{1} \text { Good to Fair/ } \\
\text { Bad/Very bad } \\
\text { health (per cent) }\end{array}$ & $\begin{array}{l}\beta^{1} \text { Fairly good to } \\
\text { Good/Very good } \\
\text { health (per cent) }\end{array}$ & $\begin{array}{l}\gamma^{1} \text { Not good to } \\
\text { Good/Very good } \\
\text { health (per cent) }\end{array}$ & $\begin{array}{l}\alpha^{1} \text { Good to Fairl } \\
\text { Bad/Very bad } \\
\text { health (per cent) }\end{array}$ & $\begin{array}{l}\beta^{1} \text { Fairly good to } \\
\text { Good/Very good } \\
\text { health (per cent) }\end{array}$ & $\begin{array}{l}\gamma^{1} \text { Not good to } \\
\text { Good/Nery good } \\
\text { health (per cent) }\end{array}$ \\
\hline $0-4$ & - & 72.3 & 33.3 & 1.6 & 73.0 & - & 0.7 & 71.8 & 14.3 \\
\hline 5-9 & 0.7 & 69.8 & 20.0 & 0.6 & 89.5 & - & 0.9 & 65.1 & 16.7 \\
\hline 10-14 & 0.7 & 71.7 & 25.0 & - & 76.5 & 50.0 & 2.0 & 67.3 & 9.1 \\
\hline 15-19 & - & 78.8 & 22.2 & 2.5 & 90.5 & 16.7 & 0.5 & 67.6 & 23.1 \\
\hline $20-24$ & 1.8 & 76.7 & 33.3 & 1.6 & 69.2 & - & 2.0 & 62.5 & 30.8 \\
\hline $25-29$ & 2.5 & 73.5 & 40.0 & 3.5 & 65.4 & 28.6 & 1.6 & 79.1 & 20.8 \\
\hline 30-34 & 2.0 & 75.3 & 23.5 & 2.2 & 64.3 & 20.0 & 3.5 & 68.8 & 10.0 \\
\hline 35-39 & 1.6 & 73.6 & 28.6 & 0.9 & 70.6 & 6.7 & 1.7 & 60.3 & 15.2 \\
\hline 40-44 & 0.5 & 73.6 & 13.0 & 5.3 & 62.5 & 18.8 & 2.6 & 66.3 & 23.5 \\
\hline $45-49$ & 3.3 & 60.2 & 35.7 & 3.5 & 71.9 & 9.1 & 2.6 & 59.8 & 14.3 \\
\hline 50-54 & 2.6 & 63.2 & 15.6 & 2.2 & 61.5 & 14.3 & 7.6 & 56.8 & 4.6 \\
\hline $55-59$ & 2.9 & 55.8 & 14.9 & 1.9 & 56.1 & 5.1 & 1.2 & 48.5 & 6.1 \\
\hline 60-64 & 2.8 & 58.9 & 16.1 & 6.0 & 62.2 & 3.0 & 4.4 & 42.0 & 11.0 \\
\hline 65-69 & 4.5 & 63.2 & 21.6 & 3.0 & 61.4 & - & 4.0 & 48.1 & 9.0 \\
\hline 70-74 & 2.7 & 50.6 & 4.7 & 2.6 & 61.9 & 16.7 & 6.5 & 47.2 & 6.3 \\
\hline 75-79 & 1.4 & 59.3 & 8.1 & 4.3 & 50.0 & 5.0 & 11.3 & 48.7 & 11.1 \\
\hline $80-84$ & 6.8 & 43.2 & 12.9 & 5.3 & 61.5 & 7.1 & 5.6 & 38.9 & 8.2 \\
\hline $85+$ & 3.4 & 61.9 & 10.5 & 10.0 & 57.1 & 8.3 & 4.3 & 51.4 & 10.0 \\
\hline Total & 1.7 & 64.6 & 17.5 & 2.4 & 65.0 & 9.1 & 2.5 & 56.1 & 11.0 \\
\hline
\end{tabular}

1 See Box Two.

Table A9

Great Britain

Adjustment factors for females by condensed HRP NS-SEC

\begin{tabular}{|c|c|c|c|c|c|c|c|c|c|}
\hline \multirow[b]{2}{*}{ Age group } & \multicolumn{3}{|c|}{ Class 1 HRP NS-SEC } & \multicolumn{3}{|c|}{ Class 2 HRP NS-SEC } & \multicolumn{3}{|c|}{ Class 3 HRP NS-SEC } \\
\hline & $\begin{array}{l}\alpha^{1} \text { Good to Fair/ } \\
\text { Bad/Very bad } \\
\text { health (per cent) }\end{array}$ & $\begin{array}{l}\beta^{1} \text { Fairly good to } \\
\text { Good/Very good } \\
\text { health (per cent) }\end{array}$ & $\begin{array}{l}\gamma^{1} \text { Not good to } \\
\text { Good/Very good } \\
\text { health (per cent) }\end{array}$ & $\begin{array}{c}\alpha^{1} \text { Good to Fair/ } \\
\text { Bad/Very bad } \\
\text { health (per cent) }\end{array}$ & $\begin{array}{l}\beta^{1} \text { Fairly good to } \\
\text { Good/Very good } \\
\text { health (per cent) }\end{array}$ & $\begin{array}{l}\gamma^{1} \text { Not good to } \\
\text { Good/Very good } \\
\text { health (per cent) }\end{array}$ & $\begin{array}{c}\alpha^{1} \text { Good to Fair/ } \\
\text { Bad/Very bad } \\
\text { health (per cent) }\end{array}$ & $\begin{array}{l}\beta^{1} \text { Fairly good to } \\
\text { Good/Very good } \\
\text { health (per cent) }\end{array}$ & $\begin{array}{l}\gamma^{1} \text { Not good to } \\
\text { Good/Very good } \\
\text { health (per cent) }\end{array}$ \\
\hline $0-4$ & 0.5 & 76.6 & 33.3 & - & 80.0 & - & - & 75.0 & 13.3 \\
\hline $5-9$ & 1.2 & 80.5 & 25.0 & 0.8 & 88.2 & - & 1.0 & 66.7 & 18.2 \\
\hline $10-14$ & - & 64.0 & 28.6 & - & 77.3 & - & - & 61.4 & - \\
\hline $15-19$ & 0.7 & 73.9 & 33.3 & 1.9 & 87.0 & - & 0.9 & 74.4 & 15.4 \\
\hline $20-24$ & 2.3 & 70.6 & 13.3 & 2.4 & 71.0 & 7.7 & 3.0 & 71.2 & 23.3 \\
\hline $25-29$ & 2.5 & 68.0 & 28.6 & 1.1 & 67.6 & 18.2 & 2.7 & 70.8 & 27.8 \\
\hline $30-34$ & 1.0 & 73.3 & 35.3 & 2.7 & 74.0 & 23.1 & 3.2 & 60.7 & 11.6 \\
\hline $35-39$ & 0.7 & 64.9 & 30.8 & 1.4 & 76.1 & 17.6 & 1.6 & 68.6 & 12.5 \\
\hline $40-44$ & 2.3 & 71.1 & 26.7 & 1.4 & 68.6 & 9.5 & 1.0 & 64.6 & 10.4 \\
\hline $45-49$ & 1.9 & 72.2 & 19.5 & 1.6 & 59.1 & 14.3 & 3.6 & 58.0 & 6.7 \\
\hline $50-54$ & 0.7 & 66.0 & 19.1 & 2.8 & 48.3 & 8.3 & 1.9 & 53.8 & 4.9 \\
\hline $55-59$ & 2.9 & 50.9 & 14.8 & 1.8 & 57.4 & 12.2 & 2.7 & 52.4 & 10.7 \\
\hline $60-64$ & 2.3 & 61.1 & 17.5 & 5.2 & 58.8 & 13.5 & 5.2 & 49.3 & 4.4 \\
\hline $65-69$ & 3.1 & 54.8 & 8.8 & 1.2 & 63.9 & 8.3 & 1.6 & 43.8 & 8.2 \\
\hline $70-74$ & - & 47.7 & 11.3 & - & 46.9 & 3.7 & 4.3 & 43.9 & 9.3 \\
\hline $75-79$ & 1.5 & 58.5 & 6.3 & 5.0 & 51.0 & 10.0 & 2.6 & 43.2 & 3.4 \\
\hline $80-84$ & 2.7 & 39.6 & 3.8 & - & 47.2 & 15.2 & 5.2 & 31.0 & 5.3 \\
\hline $85+$ & 4.5 & 57.1 & 3.8 & 11.8 & 42.9 & 5.6 & - & 37.1 & 1.9 \\
\hline Total & 1.4 & 63.8 & 17.7 & 1.7 & 62.2 & 11.1 & 1.9 & 54.5 & 8.8 \\
\hline
\end{tabular}

1 See Box Two. 
England

\begin{tabular}{|c|c|c|c|c|c|c|c|c|c|}
\hline \multirow[b]{2}{*}{ Age group } & \multicolumn{3}{|c|}{ Class 1 HRP NS-SEC } & \multicolumn{3}{|c|}{ Class 2 HRP NS-SEC } & \multicolumn{3}{|c|}{ Class 3 HRP NS-SEC } \\
\hline & $\begin{array}{l}\alpha^{1} \text { Good to Fair/ } \\
\text { Bad/Very bad } \\
\text { health (per cent) }\end{array}$ & $\begin{array}{l}\beta^{1} \text { Fairly good to } \\
\text { Good/Very good } \\
\text { health (per cent) }\end{array}$ & $\begin{array}{l}\gamma^{1} \text { Not good to } \\
\text { Good/Very good } \\
\text { health (per cent) }\end{array}$ & $\begin{array}{l}\alpha^{1} \text { Good to Fair/ } \\
\text { Bad/Very bad } \\
\text { health (per cent) }\end{array}$ & $\begin{array}{l}\beta^{1} \text { Fairly good to } \\
\text { Good/Very good } \\
\text { health (per cent) }\end{array}$ & $\begin{array}{l}\gamma^{1} \text { Not good to } \\
\text { Good/Very good } \\
\text { health (per cent) }\end{array}$ & $\begin{array}{l}\alpha^{1} \text { Good to Fair/ } \\
\text { Bad/Very bad } \\
\text { health (per cent) }\end{array}$ & $\begin{array}{l}\beta^{1} \text { Fairly good to } \\
\text { Good/Very good } \\
\text { health (per cent) }\end{array}$ & $\begin{array}{l}\gamma^{1} \text { Not good to } \\
\text { Good/Very good } \\
\text { health (per cent) }\end{array}$ \\
\hline 0-4 & - & 14.3 & 66.7 & 1.8 & 71.4 & 16.7 & 0.8 & 75.4 & 15.4 \\
\hline $5-9$ & 0.8 & 22.2 & 70.3 & 0.7 & 94.1 & - & 1.0 & 64.4 & 11.1 \\
\hline $10-14$ & 0.9 & 12.5 & 66.7 & 0.6 & 68.8 & 50.0 & 1.5 & 71.7 & 12.5 \\
\hline $15-19$ & - & 25.0 & 77.8 & 1.8 & 94.7 & 20.0 & 0.5 & 64.5 & 16.7 \\
\hline $20-24$ & 2.0 & 28.6 & 81.5 & 3.9 & 55.6 & 20.0 & 0.8 & 62.5 & 12.5 \\
\hline $25-29$ & 2.5 & 26.7 & 72.1 & 2.5 & 65.0 & 20.0 & 2.5 & 85.0 & 26.3 \\
\hline $30-34$ & 2.3 & 28.6 & 65.6 & 2.3 & 72.7 & - & 3.2 & 73.5 & 11.1 \\
\hline $35-39$ & 2.0 & 27.8 & 73.0 & 1.0 & 67.7 & 16.7 & 1.8 & 64.6 & 14.3 \\
\hline 40-44 & 0.7 & 13.0 & 72.7 & 2.0 & 65.7 & 25.0 & 3.8 & 65.7 & 22.6 \\
\hline $45-49$ & 3.4 & 19.2 & 60.0 & 2.6 & 70.6 & 15.8 & 3.3 & 65.3 & 17.5 \\
\hline 50-54 & 4.0 & 14.7 & 65.0 & 2.5 & 53.3 & 14.3 & 6.3 & 62.5 & 6.4 \\
\hline $55-59$ & 3.0 & 17.4 & 52.7 & 2.5 & 60.0 & 6.9 & 0.7 & 50.0 & 6.1 \\
\hline $60-64$ & 2.1 & 15.7 & 58.0 & 6.4 & 52.6 & 3.7 & 6.0 & 47.9 & 15.5 \\
\hline $65-69$ & 5.0 & 11.1 & 57.7 & 5.2 & 58.8 & 4.5 & 4.1 & 49.0 & 12.3 \\
\hline 70-74 & 3.0 & 4.9 & 54.8 & 3.4 & 57.6 & 23.5 & 7.3 & 47.7 & 7.0 \\
\hline $75-79$ & 2.0 & 9.1 & 56.4 & - & 61.5 & 4.5 & 6.5 & 48.6 & 11.1 \\
\hline $80-84$ & 2.6 & 7.1 & 48.6 & 9.1 & 30.0 & 16.7 & 7.5 & 35.1 & 9.5 \\
\hline $85+$ & 3.6 & 6.7 & 43.5 & - & 55.6 & 11.1 & 10.0 & 59.3 & 13.6 \\
\hline Total & 1.9 & 15.1 & 62.7 & 2.2 & 63.9 & 12.7 & 2.7 & 58.8 & 12.2 \\
\hline
\end{tabular}

1 See Box Two.

Table A11

England

\begin{tabular}{c|c|c|}
\hline \multirow{1}{*}{ Age group } & \multicolumn{3}{|c}{ Class 1 HRP NS-SEC } \\
\cline { 2 - 3 } & $\begin{array}{c}\alpha^{1} \text { Good to Fair/ } \\
\text { Bad/Very bad } \\
\text { health (per cent) }\end{array}$ & $\begin{array}{c}\beta^{1} \text { Fairly good to } \\
\text { Good/Very good } \\
\text { health (per cent) }\end{array}$ \\
\hline
\end{tabular}

\begin{tabular}{l|l|l|l|}
\hline & health (per cent) & health (per cent) \\
\hline
\end{tabular}

\begin{tabular}{|c|c|c|c|c|c|c|c|c|c|}
\hline $0-4$ & 0.6 & 73.8 & 25.0 & - & 73.9 & - & - & 72.7 & 14.3 \\
\hline $5-9$ & 1.4 & 75.7 & 22.2 & 0.9 & 81.3 & - & 1.1 & 73.2 & 22.2 \\
\hline 10-14 & - & 69.0 & 14.3 & - & 84.2 & - & - & 59.5 & 9.1 \\
\hline 15-19 & 1.3 & 72.5 & 25.0 & 1.1 & 80.0 & - & 1.0 & 78.9 & 20.0 \\
\hline $20-24$ & 2.0 & 71.4 & 15.4 & 1.4 & 66.7 & - & 3.5 & 71.7 & 24.0 \\
\hline $25-29$ & 2.5 & 62.5 & 35.3 & - & 60.7 & 10.0 & 3.5 & 71.9 & 27.6 \\
\hline $30-34$ & 1.2 & 67.6 & 26.7 & 2.1 & 74.5 & 27.3 & 2.0 & 64.2 & 16.3 \\
\hline $35-39$ & 0.8 & 65.7 & 34.2 & - & 81.8 & 13.3 & 2.3 & 60.9 & 11.8 \\
\hline $40-44$ & 2.5 & 71.9 & 21.4 & 0.8 & 68.2 & 15.0 & 1.6 & 58.7 & 12.7 \\
\hline $45-49$ & 2.0 & 75.8 & 17.1 & 1.1 & 61.5 & 11.8 & 4.2 & 55.7 & 8.5 \\
\hline $50-54$ & 0.4 & 63.2 & 19.1 & 3.4 & 47.9 & 5.3 & 0.7 & 58.2 & 5.0 \\
\hline $55-59$ & 2.7 & 57.0 & 19.2 & 1.1 & 47.2 & 5.7 & 3.0 & 55.9 & 12.1 \\
\hline $60-64$ & 2.8 & 53.4 & 13.9 & 6.3 & 64.7 & 10.3 & 6.6 & 51.4 & 9.6 \\
\hline $65-69$ & 3.0 & 55.6 & 15.2 & 1.7 & 66.7 & 8.0 & 2.7 & 43.2 & 6.8 \\
\hline $70-74$ & - & 48.2 & 7.3 & - & 37.1 & 5.3 & 5.9 & 49.6 & 13.9 \\
\hline $75-79$ & - & 56.0 & 7.7 & 6.1 & 48.5 & 4.8 & 3.3 & 43.4 & 4.3 \\
\hline $80-84$ & 3.4 & 40.0 & 5.4 & - & 47.5 & 13.0 & 3.6 & 31.1 & 7.0 \\
\hline $85+$ & 5.9 & 54.2 & 5.3 & 20.0 & 26.7 & 5.6 & - & 42.3 & 2.3 \\
\hline Total & 1.5 & 62.9 & 17.1 & 1.4 & 61.4 & 8.9 & 2.1 & 55.7 & 10.8 \\
\hline
\end{tabular}

1 See Box Two. 